\title{
PEMANFAATAN BANGUNAN BERSEJARAH SEBAGAI WISATA WARISAN BUDAYA DI KOTA MAKASSAR
}

\author{
Rafika Hayati \\ Program Studi Magister Kajian Pariwisata \\ Universitas Udayana \\ Email: fika89@mail.com
}

\begin{abstract}
Colonial period in Indonesia bequeathed a number of buildings such as schools, bank and offices. The buildings have nuance of Dutch architecture, therefore becoming cultural heritages and tourist attractions. The Aim of this research is to find out the historical buildings utilization in Makassar city, South Sulawesi Province, however in this research selected three bulidings which developed as heritage tourism, namely Fort Rotterdam, Museum Kota dan Gedung Kesenian Makassar. The three historical buildings selected as research location because of the physical potency is building architecture which completed with non physical potency is historical and cultural value. This research applied tourist attraction management, tourism area life cycle by Butler and tourism marketing theory to find out evolution life cycle of each buildings then arrange the effective strategy to develop Fort Rotterdam, Museum Kota and Gedung Kesenian as heritage tourism in Makassar city.

The article argues that the utilization of Fort Rotterdam as a tourist attraction is classified into development phase. Fort Rotterdam has been renovated several times by developing La Galigo Museum inside to increase the attractiveness. Local government has also a lot of promotions. Museum Kota and Gedung Kesenian Makassar are classified into exploration phase since the two historical buildings need physical improvement, structuring showroom and facilities to handle collections of Museum Kota and the assurance of building management and maintenance of Gedung Kesenian. Based on the result of the research Fort Rotterdam, Museum Kota dan Gedung Kesenian Makassar do not only have physical potency of building and historical value but also to become interesting tourist attraction which need improvement by maintaining architecture identity as much as possible, providing supporting facilities needed by tourists and increasing promotion by local government.
\end{abstract}

Key Word: utilization, historical buildings, heritage tourism. 


\section{Pendahuluan}

Sejarah panjang masa kolonial di Indonesia dapat dilihat sampai Odengan saat ini berupa bangunan atau benda bersejarah yang hampir terdapat di seluruh kota di Indonesia. Bangunan bersejarah tersebut saat ini keberadaannya diatur dalam Undangundang Nomor 11 tahnu 2010 tentang Cagar Budaya bahwa bahwa pemerintah, pemerintah daerah dan setiap orang dapat memanfaatkan cagar budaya untuk kepentingan agama, sosial, pendidikan, ilmu pengetahuan, teknologi, kebudayaan dan pariwisata. Pemanfaatan bangunan bersejarah merupakan bagian dari pengembangan pariwisata budaya yang merupakan salah satu faktor penarik wisatawan. Keberadaan bangunan sejarah, situs atau monumen merupakan potensi terhadap pengembangan heritage tourism atau disebut sebagai wisata warisan budaya sebagai alternatif pengembangan pariwisata di perkotaan.

Salah satu kota di Indonesia yang masih memiliki bangunan bersejarah adalah Kota Makassar merupakan ibukota dari Provinsi Sulawesi Selatan. Peraturan Menteri Kebudayaan dan Pariwisata Nomor PM.59/PW.007/MKP/2010 menyatakan bahwa terdapat 19 bangunan bersejarah di Kota Makassar yang ditetapkan sebagai bangunan cagar budaya. Artikel ini bertujuan untuk mengangkat peran beberapa bangunan bersejarah di Kota Makassar sebagai daya tarik wisata. Bangunan yang difokuskan pada tiga bangunan bersejarah yaitu Fort Rotterdam, Museum Kota dan Gedung Kesenian. Alasan pemilihan ketiga bangunan sebagai fokus di dalam artikel ini, karena ketiga bangunan tersebut memiliki keunikan arsitektur bangunan yang dilengkapi dengan nilai sejarah dan budaya yang melekat pada masing-masing bangunan sehingga pengembangan wisata kota lama. Semakin tingginya minat akan pariwisata budaya diharapkan Kota Makassar dapat berpartisipasi sebagai salah satu destinasi wisata warisan budaya di Indonesia.

Pemanfaatan bangunan bersejarah sebagai produk pariwisata merupakan salah satu jalan keluar bangunan-bangunan tersebut dapat terus bertahan dengan semakin banyaknya fasilitas modern

$2 \quad$ JUMPA Volume 01, Nomor 01, Juli 2014 
di sekelilingnya. Pemanfaatan bangunan bersejarah sebagai daya tarik wisata juga memiliki tantangan yang berat, karena selain harus membawa dampak ekonomi bagi masyarakat juga memerlukan langkah-langkah pelestarian.

Artikel ini menguraikan pemanfaatan Fort Rotterdam, Museum Kota dan Gedung Kesenian sebagai wisata warisan budaya, kemudian menetapkan tahap perkembangan dengan terlebih dahulu menguraikan potensi internal dan eksternal masing-masing bangunan sehingga dapat ditentukan strategi yang efektif untuk meningkatkan Fort Rotterdam, Museum Kota dan Gedung Kesenian sebagai wisata warisan budaya di Kota Makassar

\section{Teori dan Metode}

Artikel ini menggunakan beberapa konsep antara lain, bangunan bersejarah, wisata warisan budaya, daya tarik wisata dan strategi. Adapun teori yang di dalam artikel menggunakan teori manajemen daya tarik wisata dimana pengelolaan terhadap daya tarik wisata warisan budaya memiliki kesulitan tersendiri karena pembangunan sarana prasarana pendukung kegiatan wisata harus memperhatikan prinsip-prinsip pelestarian bangungan bersejarah. Teori siklus hidup destinasi wisata yang dikembangakan oleh Butler (1980) yang dipergunakan untuk mengetahui tahap perkembangan masing-masing bangunan bersejarah sebagai daya tarik wisata sedangkan teori pemasaran pariwisata yang dibatasi pada unsur promosi dari konsep 4P bauran pemasaran terdiri dari public relation, advertising, graphic material dan promotion digunakan sebagai salah satu tolak ukur dalam penentuan tahap perkembangan dari faktor promosi wisata.

Artikel ini menggunakan pendekatan kualitatif yang fokus pada tiga bangunan bersejarah, yaitu Fort Rotterdam, Museum Kota, dan Gedung Kesenian Makassar. Metode dan teknik pengumpulan data dengan teknik observasi sistematik, teknik wawancara semi terstruktur dengan penentuan informan 
menggunakan teknik purposif dan teknik dokumentasi. Informan tersebut terdiri dari pengelola Fort Rotterdam dalam hal ini Dinas Pariwisata dan Ekonomi Kreatif Provinsi Sulawesi Selatan, Balai Pelestarian Cagar Budaya Kota Makassar, Pengelola Museum La Galigo. Pengelola Museum Kota dan seniman pengelola Gedung Kesenian, akademisi pariwisata Kota Makassar, pramuwisata serta organisasi Ujung Pandang Heritage Society. Metode dan teknik analisis data di dalam artikel ini dimulai dari reduksi data, penyajian data dan penarikan kesimpulan. Metode dan teknik dan penyajian hasil analisis data diuraikan dalam delapan bab secara naratif.

\section{Lokasi Strategis}

Kota Makassar memiliki lokasi yang strategis sehingga menjadi pintu masuk bagi kota-kota di kawasan Indonesia Timur. Beberapa tahun terakhir ini perkembangan bisnis dan industri di Kota Makassar semakin menjamur, seperti perkembangan bisnis restoran, hotel, pusat perbelanjaan dan industri lainnya.

Kota Makassar sebagai bagian dari indutsri pariwisata terus berbenah diri dan mulai membangun fasilitas juga dalam menyukseskan visi Kota Makassar sebagai 'kota dunia'. Perkembangan hotel di Kota Makassar dimuat dalam satu harian online pada tahun 2013 sebesar $65 \%$ yang mengacu pada hotel yang sudah dan sedang dalam proses pembangunan akan bertambah sebanyak 4.468 kamar. Pembangunan daya tarik wisata moderen seperi indoor theme park,wahan air yang lengkap dengan kebun binatang mini serta pembangunan fasilitas convention centre dengan kapasitas daya tampung ribuan orang.

Dinyatakan oleh Meutia Hatta dalam salah satu seminarnya di Kota Makassar bahwa apabila Kota Makassar menuju kota dunia pemerintah daerah harus memelihara kultur budaya serta memperhatikan kemiskinan, kesejahteraan rakyat dan menjaga nuansa budaya salah satunya ialah bangunan yang dianggap 
bersejarah ${ }^{1}$. Beberapa bangunan bersejarah di Kota Makassar yang telah ditetapkan sebagai bangunan cagar budaya telah dialihfungsikan sebagai kantor pemerintahan, tempat ibadah atau pemukiman pribadi serta menjadi daya tarik wisata. Fort Rotterdam sebagai lambang kejayaan Kerajaan Gowa, dibangun pada abad ke16 dan17yang kemudian diambilaliholeh pemerintah Belanda. saat ini dengan arsitektur Belanda gaya gotik dari abad XVII telah menjadi daya tarik wisata andalan di Kota Makassar. Fort Rotterdam terdiri dari 16 bangunan dan seluruh bangunan tersebut terawat dengan baik. Museum Kota Makassar atau yang dulu dikenal dengan nama Gemeentehuis adalah bangunan kolonial yang dibangun tahun 1906 dan awalnya berfungsi sebagai kantor walikota. Gedung Kesenian Makassar dibangun pada tahun 1890-an yang berfungsi sebagai tempat perjamuan, pesta dansa, pertunjukan sandiwara pada masa kolonial.

Fort Rotterdam, Museum Kota dan Gedung Kesenian Makassar adalah beberapa bangunan bersejarah yang masih berdiri. Ketiga bangunan bersejarah tersebut memiliki potensi dikembangkan sebagai wisata warisan budaya arsitekrnya yang bernilai serta nilai sejarah serta budaya yang terkandung di dalam masing-masing bangunan.

\section{Bangunan Bersejarah sebagai Wisata Warisan Budaya}

Pemanfaatan Fort Rotterdam atau dikenal juga dengan nama Benteng Ujung Pandang pada abad ke-16 dan 17 dimanfaatkan oleh Kerajaan Gowa sebagai benteng pertahanan. Diserahkan kepada pihak Belanda melalui perjanjian Bungaya tahun 1667 yang mengubah arsitektur bangunan dan pemanfaatannya. Pemerintah kolonial membangun 15 buah bangunan dengan gaya aristektur gotik dari abad XVII. Fort Rotterdam berfungsi sebagai pemukiman, tempatibadah, pusat perdagangandan pemerintahan. Pemanfaatan Fort Rotterdam pada masa kekuasaan Jepang di

1 Borahim, Khaeruddin 2013. Mau Jadi Kota Dunia, Makassar Perlu Perhatikan Bangunan Sejarah dan Kemiskinan, [Diunduh 10 November 2013]. Sumber: URL: http:// rri.co.id/index.php/berita/69514/Mau-Jadi-Kota-Dunia-Makassar-Perlu-PerhatikanBangunan-Sejarah-dan-Kemiskinan 


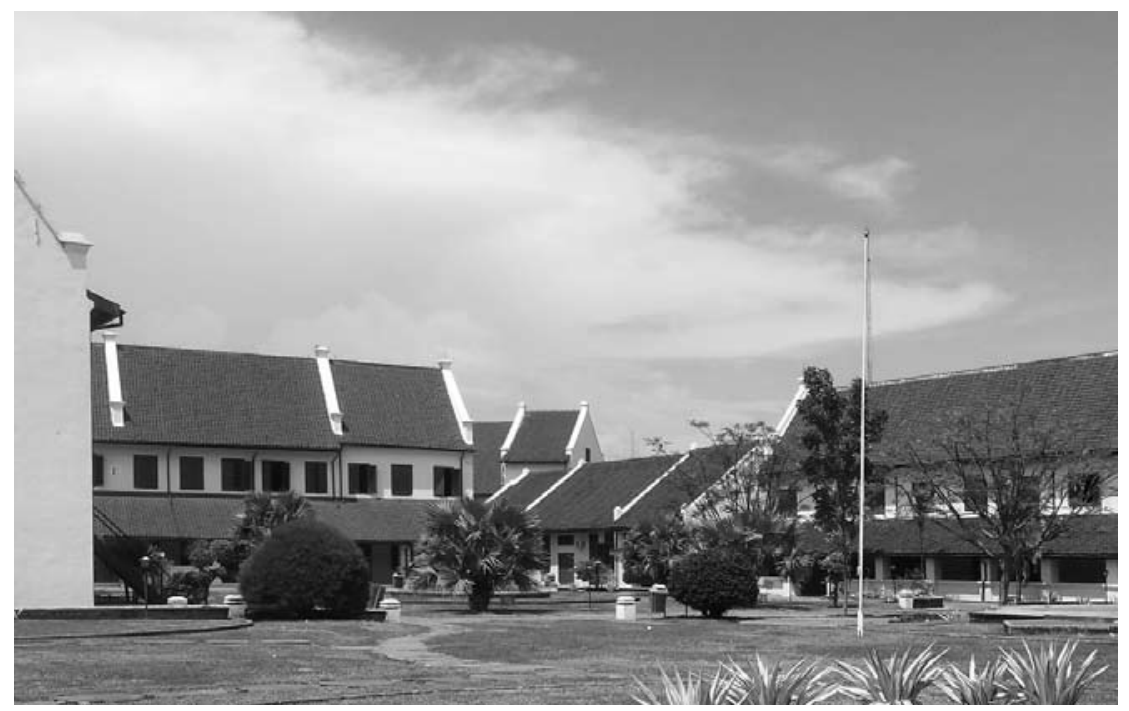

Fort Rotterdam Makassar

Kota Makassar sebagai Kantor Pusat Penelitian Ilmiah dalam Ilmu Pertanian dan Bahasa serta ditambahkan sebuah gedung berlantai satu dengan arsitektur yang serupa dengan bangunan lainnya. Pemerintah Indonesia kemudian memanfaatkan Fort Rotterdam sebagai Pusat Kebudayaan Sulawesi Selatan serta daya tarik wisata pada tahun 1974.

Sebelum keputusan resmi pemanfaatan Fort Rotterdam sebagai pusat kesenian dikeluarkan oleh pemerintah telah dilaksanakanpembenahan terhadapfisikbangunan.Pembangunan jalan setapak yang menghubungkan antar gedung, pemugaran beberapa gedung yang rusak, pembangunan arena terbuka yang berfungsi sebagai tempat latihan dan pertunjukan tari serta pembukaan kembali Museum Celebes yang dahulu merupakan museum pribadi bagi pemerintah kolonial, kemudian berganti nama menjadi Museum La Galigo. Pemanfaatan Fort Rotterdam sebagai daya tarik wisata menjadikannya banyak dikunjungi oleh tidak hanya wisatawan tetapi juga masyarakat lokal sampai saat ini. Pemerintah Kota Makassar telah banyak dilaksanakan langkah pelestarian antara lain revitalisasi tahun 2010-2011 pada seluruh bangunan di dalam kompleks Fort Rotterdam dan pengembalian

$6 \quad$ JUMPA Volume 01, Nomor 01, Juli 2014 


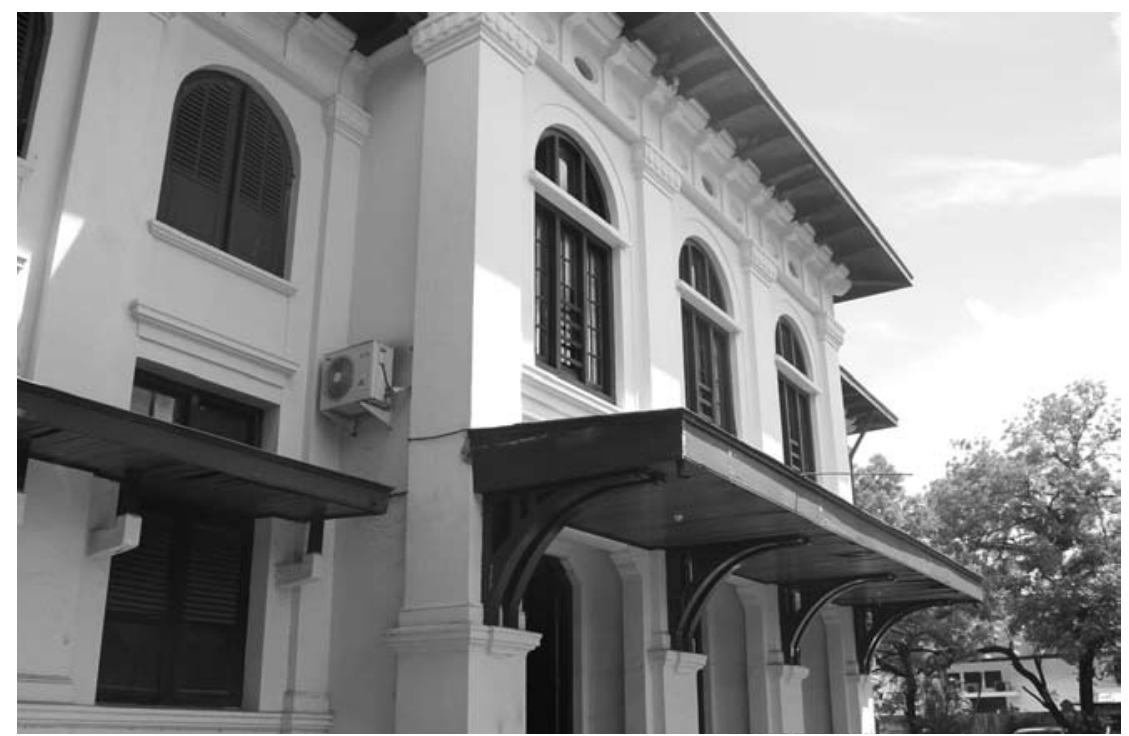

Museum Kota Makassar

penampakan Fort Rotterdam dari luar yang dikelilingi oleh kanal, akan tetapi baru pada bagian selatan bangunan yang telah terwujud oleh karena telah banyakpusat perkantoran dan rumah penduduk yang dibangun disekitar Fort Rotterdam.

Museum Kota Makassar pada awal pembangunannya oleh pemerintah kolonial dimanfaatkan sebagai Kantor Walikota (Gementeehuis) Makassar, sampai masa kekuasaan Belanda berakhir di Indonesia gedung ini tidak berubah fungsinya. Pemanfataan Gementeehuis oleh Pemerintah Indonesia antara lain sebagai kantor BAPPEDA dan kantor catatan sipil kemudian tahun 2000 diresmikan menjadi Museum Kota Makassar.

Museum Kota Makassar yang masih dalam status museum persiapan menyebabkan pemanfatan museum kota memiliki beberapa hambatan, antara lain kerusakan pada atap yang menyebabkan kebocoran di salah satu bagian ruangan. Kelembaban pada dinding yang mengakibatkan timbulnya jamur, toilet bagi pengunjung yang tidak begitu terawat. Pembangunan awal gedung memiliki konsep garden city yang membuat areal depan Museum Kota dikelilingi oleh pohon besar sehingga halaman Museum Kota Makassar akhirnya dimanfaatkan sebagai 


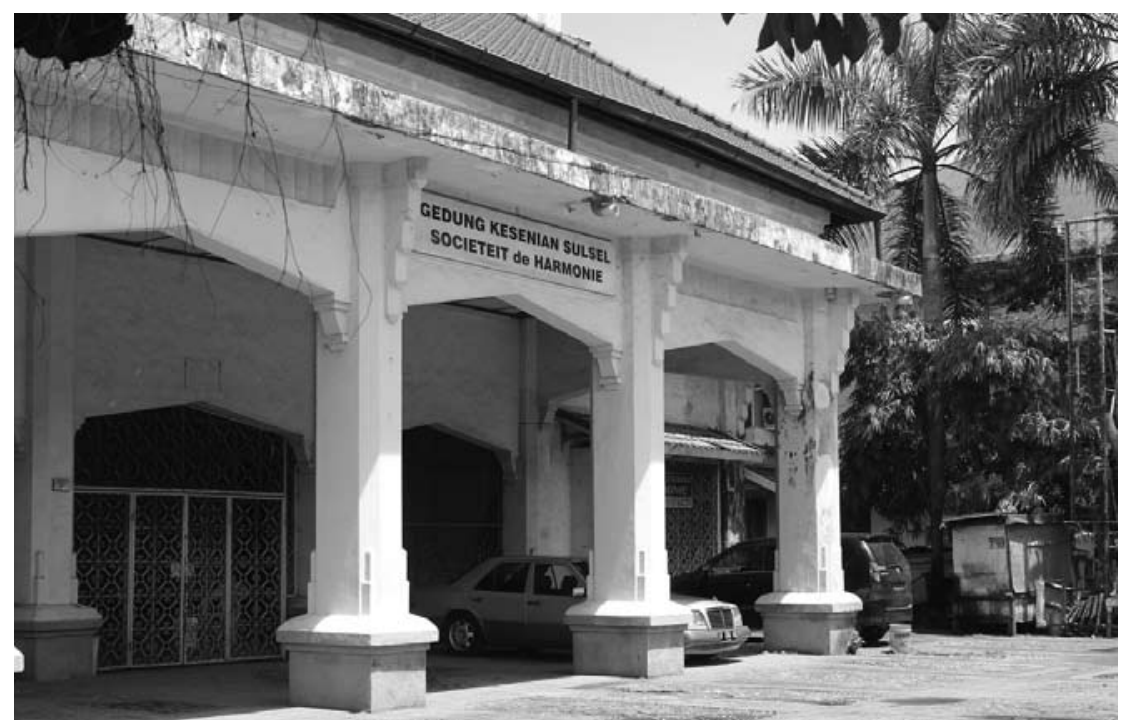

Gedung Kesenian Makassar

lahan parkir dan terkadang mobil-mobil yang terparkir di depan museum menutupi pemandangan ke dalam bangunan. Museum Kota Makassar memiliki potensi untuk dimanfaatkan sebagai daya tarik wisata yang berkualitas. Bangunan bersejarah, koleksi benda cagar budaya secara keseluruhan memerlukan pengelolaan yang baik.

Gedung Kesenian Makassar awal pendiriannya bertujuan sebagai gedung yang dapat mengakomodasi acara-acara resmi pemerintah kolonial dengan mitra dagang mereka. Pemanfaatan dengan tujuan tersebut oleh pemerintah Belanda berlangsung dari awal pembuatan Gedung Kesenian Makassar tahun 1890-an hingga pada tahun 1910 direnovasi menjadi bentuknya saat ini. Pemanfaatan sebagai tempat diselenggarakan acara resmi kemudian terhenti setelah masa kekuasaan Jepang tahun 1942-1953 yang memanfaatkan Gedung Kesenian sebagai Balai Pertemuan Masyarakat. Setelah Indonesia merdeka Gedung Kesenian beberapa kali menjadi kantor pemerintahan dari tahun 1953-2000.

Pemerintah memutuskan Gedung Kesenian kembali dimanfaatkan sebagai tempat pagelaran dan perkembangan seni sampai dengan saat ini. Selama proses pemanfaatan tersebut 
tidak banyak penambahan bangunan, hanya terdapat perubahan dan pembuatan beberapa ruangan sesuai dengan pemanfaatan bangunan pada saat tersebut. Pemanfaatan Gedung Kesenian sebagai pusat pengembangan kegiatan seni tradisional maupun kegiatan lainnya memiliki banyak kendala. Secara fisik bangunan tidak memadai, tampak depan bangunan Gedung Kesenian Makassar terlihat usang oleh megahnya beberapa bangunanbangunan baru di sekitarnya. Sebelah timur aula terdapat ruangan yang di dalamnya banyak tumpukan kayu, bambu dan sampah. Sebelah barat aula terlihat lemari yang menyimpan buku-buku kesenian dan ruangan yang dijadikan kantin.

Pariwisata merupakan salah satu jalan pelestarian terhadap Fort Rotterdam, Museum Kota, dan Gedung Kesenian, akan tetapi memerlukan usaha dan kerjasama dari berbagai pihak. Pengembangan daya tarik wisata menuntutnya tidak hanya memiliki keunikan, tetapi layak untuk dikunjungi bagi wisatawan. Ketiga bangunan bersejarah diharapkan dapat menjadi pelengkap terhadap daya tarik wisata moderen seperti Trans Studio yang dilengkapi dengan mall serta pembangunan wahana permainan air, antara lain Bugis Waterpark dan Gowa Discovery Park dan pembangunan beberapa pusat perbelanjaan lainnya. Keberadaan daya tarik wisata moderen tersebut dengan penataan yang apik, bersih serta hiburan sehingga pengunjung merasa betah menghabiskan waktu lama di lokasi-lokasi tersebut. Pada kenyataannya adanya daya tarik wisata modern tidak memberikan dampak penurunan atau kenaikan pada kunjungan di Fort Rotterdam, Museum Kota, dan Gedung Kesenian Makassar, tetapi dapat mengikis kecintaan masyarakat lokal terhadap bangunan bersejarah sehingga langkah-langkah pelestarian dan perawatan bangunan bersejarah secara perlahan mulai terkikis demi terwujudnya pembangunan daya tarik wisata moderen untuk memenuhi permintaan.

Fort Rotterdam, Museum Kota dan Gedung Kesenian saat ini menjadi daya tarik wisata khusus bagi beberapa kalangan yang memiliki ketertarikan khusus kepada sejarah dan kebudayaan 
suatu daerah. Trans Studio, Bugis Waterpark dan Gowa Discovery Park lebih banyak digemari oleh pengunjung dengan tipe keluarga oleh karena dalam satu tempat dapat mencakup seluruh kebutuhan wisata keluarga.

\section{Tahap Perkembangan Wisata Warisan Budaya di Kota Makassar}

Tahap perkembangan Fort Rotterdam, Museum Kota dan Gedung Kesenian Makassar ditentukan melalui siklus hidup destinasi wisata yang dikembangkan oleh Butler. Sebelum menentukan tahap perkembangan masing-masing bangunan sebagai daya tarik wisata terlebih dahulu dijabarkan faktor attraction, accessibility, amenities, available packages, activities, ancilary service yang ditambah dengan faktor promosi wisata.

\subsection{Faktor Atraksi Wisata}

Perkembangan daya tarik wisata dapat diukur melalui peningkatan jumlah wisatawan serta didukung pula dengan penataan daya tarik wisata yang baik. Fort Rotterdam sebagai bangunan bersejarah kondisinya saat ini terawat dengan baik, penataan di dalam kompleks bangunan Fort Rotterdam memiliki taman bunga sehingga memungkinkan pengunjung atau wisatawan untuk berlama-lama menghabiskan waktu di dalam kompleks Fort Rotterdam. Menurut salah satu akademisi bidang pariwisata di Kota Makassar (Farid. 2014) bahwa wisatawan dari Asia, seperti Singapura, Malaysia, Cina, dan Jepang yang datang ke Kota Makassar menyatakan bahwa Fort Rotterdam adalah satu-satunya daya tarik wisata yang tertata apik, rapi, dan layak jual, sementara lainnya belum layak jual.

Fort Rotterdam sebagai bangunan cagar budaya dan daya tarik wisata telah disusun zonasi cagar budaya oleh Balai Pelestarian Cagar Budaya Makassar sehingga pembangunan di sekitarnya dapat disesuaikan dengan langkah-langkah pelestarian bangunan. Menurut Peraturan Peraturan Daerah Kota Makassar nomor 6 tahun 2006 tentang Rencana Tata Ruang Wilayah Kota Makassar bahwa strategi pengembangan kawasan khusus kon- 
servasi budaya adalah mendukung program pelestarian budaya (lingkungan dan bangunan) melalui penataan kembali kawasan konservasi budaya yang bisa tetap bersinergi dengan pertumbuhan lingkungan sekitarnya. Pada kenyataannya beberapa pembangunan di sekitar Fort Rotterdam sulit untuk di kendalikan sesuai dengan zonasi dan rencana tata ruang wilayah yang telah dibuat.

Museum sebagai salah satu daya tarik wisata selain memamerkan koleksi benda cagar budaya juga memerlukan pengaturan yang baik sehingga pengunjung tidak merasa bosan. Penataan ruang pamer pada museum kota harus didukung fasilitas yang menunjang kenyamanan bagi pengunjung dan koleksi yang disimpan. Kondisi museum yang tidak memiliki pendingin ruangan dengan suhu yang sesuai untuk suatu barang yang berusia lama serta pencahayaan yang hanya mengandalkan cahaya matahari dapat membawa kerusakan bagi benda-benda bersejarah. Atraksi wisata buatan seperti museum, istana, candi atau bangunan bersejarah lain membutuhkan modernitas baik segi fisik bangunan, pengelolaan yang membawa kesan dan pengalaman bagi wisatawan. Museum tidak hanya dipergunakan sebagai wadah penyimpanan benda bersejarah dan budaya akan tetapi museum juga diharapkan sebagai daya tarik wisata yang mampu menarik wisatawan.

Bangunan bersejarah lainnya yang masih dapat dilihat di Kota Makassar adalah Gedung Kesenian (societiet de harmonie) yang terletak tidak jauh dari Fort Rotterdam dan Museum Kota Makassar. Gedung Kesenian dengan kondisi saat ini dapat dikatakan belum layak sebagai daya tarik wisata atau pusat pertunjukan seni di Kota Makassar. Kondisi bangunan yang terbengkalai, kurangnya data-data event yang pernah dilaksanakan dan pengelolaan yang masih belum jelas merupakan kendala utama. Tahun 2014 Gedung Kesenian Makassar direncanakan direvitalisasi oleh Dinas Pariwisata dan Ekonomi Kreatif Provinsi Sulawesi Selatan.

Pengembangan Fort Rotterdam, Museum Kota, dan Gedung 
Kesenian sebagai wisata warisan budaya memiliki perbedaan sehingga terjadi perbedaan jumlah pengunjung dan pengelolaan. Fort Rotterdam sebagai daya tarik wisata telah banyak dikenal oleh wisatawan dan masyarakat lokal yang menjadikan Fort Rotterdam sebagai tempat berkumpul dan melaksanakan beberapa kegiatan organisasi pemuda. Pada tahun 2013 jumlah pengunjung domestik sebanyak 16.389 orang sedangkan pengunjung mancanegara sebesar 345 orang. Museum Kota Makassar meskipun tidak memiliki luas bangunan seperti Fort Rotterdam akan tetapi memiliki potensi sebagai daya tarik wisata. Pada tahun 2013 jumlah kunjungan domestik yang didominasi oleh siswa sekolah sebanyak 2.033 orang sedangkan wisatawan mancanegara hanya 60 orang. Gedung Kesenian Makassar belum memiliki sistem pencatatan untuk jumlah pengunjung serta event yang telah diselenggarakan.

\subsection{Faktor Aksesibilitas}

Fort Rotterdam, Museum Kota dan Gedung Kesenian berada di pusat Kota Makassar dan berlokasi tidak jauh dari masing-masing bangunan. Museum Kota terletak di sebelah timur dan Gedung Kesenian terletak di sebelah Utara Fort Rotterdam. Mencapai ketiga bangunan bersejarah tersebut dapat menggunakan angkutan umum seperti taksi, becak dan pete-pete. Moda transportasi untuk mencapai Kota Makassar sendiri telah cukup lengkap, penerbangan komersil dari kota-kota besar di Indonesia telah melayani penerbangan langsung ke Kota Makassar dan telah tersedia penerbangan internasional dari Singapura dan Malaysia langsung ke Makassar.

\subsection{Faktor Fasilitas Penunjang Pariwisata}

Pembangunan industri pariwisata berawal dari adanya permintaan (demand) sehingga hadir produsen untuk memenuhi permintaan tersebut. Kebutuhan wisatawan tidak hanya berupa daya tarik wisata tetapi juga kebutuhan akan jasa. Terjadi peningkatan jumlah akomodasi mulai dari hotel berbintang 
sampai dengan penginapan dengan budget rendah, pada tahun 2012 jumlah kamar hotel di Kota Makassar sebanyak 6.918 kamar, tahun 2013 ada penambahan sebanyak 4.468 kamar $^{2}$.

Pramuwisata juga menjadi salah satu kebutuhan wisatawan. Dinyatakan oleh Sekretaris HPI Sulawesi Selatan Mukhtar bahwa di Sulwesi Selatan terdapat 280 pramuwisata yang mempunyai lisensi madya (menengah) ${ }^{3}$. Pramuwisata sebagai kebutuhan dalam perjalanan wisata di Kota Makassar telah tersedia dan dalam berbagai bahasa. Perkembangan bisnis kuliner beberapa tahun ini mengalami perkembangan yang cukup pesat. Jenis restoran atau kafe yang mulai bermunculan di Makassar juga beragam baik makanan internasional, khas daerah Makassar dan berbagai daerah di Provinsi Sulawesi Selatan.

Fasilitas penunjang pariwisata sebagai salah satu landasan dalam penentuan tahap perkembangan Fort Rotterdam, Museum Kota dan Gedung Kesenian sebagai wisata warisan budaya tidak menjadi kendala. Secara umum Kota Makassar telah berbenah dengan membangun fasilitas hotel, restoran, tempat hiburan malam dan penyediaan pramuwisata.

\subsection{Faktor Ketersediaan paket Wisata}

Industri pariwisata tidak bisa lepas dari adanya biro perjalanan wisata sebagai salah satu pihak yang mendatangkan wisatawan ke daerah tujuan wisata. Melalui paket wisata yang dipasarkan oleh biro perjalanan di Kota Makassar kepada wisatawan Fort Rotterdam merupakan daya tarik wisata yang lebih banyak dijual di dalam paket wisata. Museum Kota dan Gedung Kesenian masih menjadi daya tarik wisata bagi kalangan tertentu.

2 Dammar, Suwarny. Booming Hotel Di Makassar-Bencana atau Peluang?. [diunduh 18 April 2014]. Sumber: URL: http://m.koran-sindo.com/node/321586.

3 Anonim. Sulsel miliki 280 pemandu wisata berlisensi. [diunduh 21 April 2014]. Sumber: URL: http://antara-sulawesiselatan.com/berita/24076/sulsel-miliki-280pemandu-wisata-berlisensi. 


\subsection{Faktor Aktivitas di Daya Tarik Wisata}

Aktivitas pada suatu daya tarik wisata adalah sisi lain yang menambah minat wisatawan untuk mengunjungi daya tarik wisata tersebut. Aktivitas yang saat ini dapat dilakukan oleh pengunjung di sekitar Fort Rotterdam tidak begitu banyak, beberapa organisasi pemuda duduk dan menikmati waktu sore atau sekedar mencari sudut gambar yang menarik di beberapa sisi bangunan. Museum La Galigo yang berada di dalam Fort Rotterdam oleh pengelola tidak banyak terdapat aktivitas di dalam museum. Museum La Galigo lebih banyak memberikan kegiatan kepada siswa sekolah.

Museum Kota Makassar selain memamerkan benda-benda bersejarah belum banyak memiliki aktivitas tambahan yang dapat dilakukan di museum. Pengunjung hanya melihat koleksi museum melalui lemari kaca dan foto Kota Makassar zaman kolonial dan pejabat daerah dari masa ke masa. Aktivitas wisata dan pertunjukan seni di Gedung Kesenian Makassar belum banyak yang dapat dilakukan, karena kondisi gedung yang masih proses perbaikan yang belum terselesaikan.

\subsection{Faktor Pelayanan Pendukung}

Ancillary service merupakan pelayanan pendukung yang dibutuhkan wisatawan selama berada di daerah tujuan wisata. Pelayanan pendukungberupalayanan telekomunikasi, perbankan, pos, penukaran uang dan kesehatan yang berstandar internasional telah tersedia di Kota Makassar sebagai salah satu kota besar di Indonesia Timur. Pelayanan pendukung yang telah tersedia di Kota Makassar bagi wisatawan dapat dikatakan cukup lengkap akan tetapi peningkatan justru harus dilakukan pada daya tarik wisata sehingga dapat meninggalkan kesan pada wisatawan.

\subsection{Faktor Promosi Wisata}

Fort Rotterdam sebagai destinasi wisata unggulan di Kota Makassar telah banyak dipromosikan. Beberapa kegiatan promosi Dinas Pariwisata dan Ekonomi Kreatif Sulawesi Selatan adalah MATTA (Malaysia's Premiere Travel Extravaganza) di Kuala Lumpur 
dan NATAS (National Association Of Travel Agents Singapore) Travel Fair di Singapura dan Pameran Pariwisata International Tourism Bourse (ITB) Berlin, Jerman oleh Dinas Pariwisata dan Ekonomi Kreatif Kota Makassar.

Kegiatan lain berupa kunjungan 12 jurnalis dari Malaysia dalam rangka mempromosikan pariwisata di Kota Makassar. Kegiatan educational tour bagi siswa sekolah. Pengorganisasian educational tour ini dilaksanakan oleh pengelola Museum La Galigo.

Museum Kota sendiri adalah kerjasama untuk educational tour. Siswa-siswa dari berbagai sekolah di Kota Makassar banyak melalukan kunjungan secara rombongan atau individu. Selain itu, website lainnya yang memuat tentang Museum Kota Makassar antara lain: www.indonesia.travel.com, www. asosiasimuseumindonesia.org, www.museumku.wordpress.com dan www.wisatamelayu.com. Kunjungan beberapa jurnalis lokal dan nasional ke Museum Kota merupakan sarana yang membantu promosi dari pihak pengelola.

Belum banyak kegiatan promosi bagi Gedung Kesenian Makassar dalam usahanya sebagai salah satu destinasi wisata di Kota Makassar. Gedung Kesenian selama ini masih menjadi rumah bagi para seniman lokal untuk mengembangkan karyanya. Gedung Kesenian lebih banyak diinformasikan melalu lisan dari sesama seniman.

Melalui enam komponen antara lain activities, accessibilty, amenities, available package, activities, ancillary service ditambah dengan komponen promosi wisata, disimpulkan tahap perkembangan Fort Rotterdam berada pada tahap pengembangan (development), Museum Kota pada tahap eksplorasi (exploration) dan Gedung Kesenian pada tahap eksplorasi (exploration) sebagai wisata warisan budaya di Kota Makassar.

\section{Strategi yang Efektif}

Strategi yang dimaksud dalam artikel ini adalah gagasangagasan yang diperuntukkan bagi masing-masing bangunan 
bersejarah dalam pemanfaatannya sebagai wisata warisan budaya. Strategi yang digunakan untuk penelitian ini adalah strategi intensif yang terdiri dari pengembangan produk, penetrasi pasar dan pengembangan pasar. Strategi intesif dipilih sebagai strategi pengembangan Fort Rotterdam, Museum Kota dan Gedung Kesenian karena ketiga bangunan bersejarah tersebut memiliki potensi sebagai produk pariwisata sehingga memerlukan usahausaha intensif untuk dapat bersaing dengan daya tarik wisata lainnya di berbagai daerah di Indonesia.

\subsection{Fort Rotterdam}

Langkah-langkah dalam implementasi strategi pengembangan produk pada Fort Rotterdam, antara lain: pengembangan kawasan di sekitar Fort Rotterdam seharusnya sesuai dengan Perda Kota Makassar nomor 6 tahun 2006 tentang Rencana Tata Ruang Wilayah Kota Makassar serta aturan zonasi oleh Balai Pelestarian Cagar Budaya. Pembangunan Kota Makassar seharusnya dapat bersinergi dengan keberadaan bangunan cagar budaya. Perlu adanya atraksi yang dapat bersentuhan langsung dengan wisatawan yang mengunjungi museum seperti peragaan terhadap alat musik yang juga bisa dipraktekan oleh wisatawan.

Peningkatan standarisasi pelayanan sumber daya manusia yang menguasai bahasa asing, fasilitas umum yang berstandar bagi wisatawan, seperti toilet di sekitar area Fort Rotterdam dan peningkatan perawatan terhadap kebersihan lingkungan di sekitar kompleks Fort Rotterdam. Pengembangan wisata kota lama bagi siswa sekolah, mahasiswa dan wisatawan.

Langkah-langkah implementasi pada strategi penetrasi dan pengembangan pasar terhadap Fort Rotterdam berupa perbaikan terhadap pelayanan informasi website yang tersedia dalam berbagai bahasa, pengelompokan daya tarik wisata sesuai dengan jenis, seperti wisata warisan budaya, alam atau minat khusus sehingga dapat menarik pasar wisatawan baru. Menjalin kerjasama dengan mitra kerja dari berbagai travel fair yang telah dihadiri. Pembuatan newsletter yang dikirimkan melalui email 
sehingga kegiatan promosi yang terus-menerus dapat dilakukan.

Mencoba memperluas target yang telah dilaksanakan oleh Dinas Pariwisata dan Ekonomi Kreatif yaitu warga negara Malaysia dan Singapura keturunan Sulawesi Selatan untuk wisata mudik, hal yang sama dapat dilakukan ke beberapa negara Asia dan Australia. Pengadaan website tersendiri bagi Fort Rotterdam yang memuat tidak hanya informasi, lokasi, jadwal event yang akan berlangsung di Fort Rotterdam dan Museum La Galigo serta meningkatkan kerjasama dengan dari berbagai tingkatan sekolah dasar, menegah pertama dan menengah atas untuk mengunjungi Fort Rotterdam dan menanamkan kecintaan kepada bangunan bersejarah.

\subsection{Museum Kota Makassar}

Hasil dari temuan yang didapatkan selama observasi menghasilkan penyusunan langkah-langkah strategi pengembangan produkyang terdiridari, perbaikanfisikbangunanMuseum Kota Makassar berupa perbaikan terhadap kerusakan langit-langit, pengelupasan cat pada dinding yang meninggalkan kesan tidak terawat pada bangunan. Pembaharuan fasilitas museum berupa lemari atau kotak yang digunakan untuk memamerkan koleksi, pencahayaan dan suhu ruangan. Peningkatan kualitas pelayanan penguasaan bahasa asing dan penyediaan ahli perawatan koleksi museum. Guna meningkatkan kontribusi pendapatan, diperlukan penjualan tiket masuk museum setelah adanya perbaikan Museum Kota Makassar.

Implementasi pada strategi penetrasi dan pengembangan pasar terhadap Museum Kota Makassar, antara lain yang target utama kunjungannya oleh siswa sekolah melalui strategi perbaikan fisik bangunan dan pembenahan kualitas museum dapat meningkatkan tingkat kunjungan wisatawan mancanegara dan nusantara dengan mengadakan kerjasama terhadap pihak HPI, ASITA, PHRI serta organisasi pariwisata lainnya. Target pasar siswa sekolah yang telah dilaksanakan saat ini dikembangkan kepada siswa sekolah diluar Kota Makassar. 


\subsection{Gedung Kesenian Makassar}

Terdapat beberapa langkah yang perlu dilaksanakan dalam rangka pengembangan Gedung Kesenian sebagai produk wisata di Kota Makassar. Perbaikan terhadap tampilan fisik Gedung Kesenian, mulai dari menghilangkan kesan kumuh terhadap warna dinding, perbaikan panggung ruang pertunjukan tertutup, perbaikan ruang pertunjukan terbuka, perbaikan langitlangit yang telah mengalami kebocoran. Perbaikan Gedung Kesenian bertujuan membuatnya menjadi layak untuk dikunjungi dan sebagai pusat perkembangan seni di Kota Makassar. Penambahan fasilitas modern tanpa meninggalkan keaslian dan tetap mempertahankan arsitektur bangunan. Fasilitas yang dimaksud adalah pencahayaan panggung, pengeras suara dan fasilitas lain yang mendukung pertunjukan seni. Adanya fasilitas galeri yang memberikan pemahaman sejarah bangunan, perkembangan seni dan perpustakaan. Pengelolaan yang lebih jelas. Diperlukan pengelola khusus dari pemerintah tentang perawatan, penyewaan gedung sehingga adanya pihak yang menjembatani komunikasi antara seniman dan pemerintah selaku pemilik Gedung Kesenian.

Langkah-langkah bagi strategi penetrasi pasar dan pengembangan pasar untuk Gedung Kesenian yaitu: Gedung Kesenian merupakan bagian dari sejarah Kota Makassar sehingga memiliki potensi yang dapat dikembangkan bagi produk wisata. target pasar pengunjung Gedung Kesenian, dari hanya penggiat seni menjadi wisatawan mancanegara dan nusantara. Menjalin kerjasama dengan biro perjalanan wisata dan organisasi pariwisata Adanya website khusus bagi Gedung Kesenian yang menyajikan jadwal pertunjukan seni, pemutaran film dan pertunjukan tarian tradisional sehingga mudah diakses oleh wisatawan.

\section{Penutup}

Berdasarkan hasil penelitian yang telah diuraikan dapat disimpulkan bahwa pemanfaatan beberapa bangunan bersejarah di Kota Makassar saat ini berfungsi sebagai daya tarik wisata. Beberapa bangunan bersejarah tersebut adalah Fort Rotterdam 
dan Museum Kota yang dahulu sebagai pusat pemerintahan dan Gedung Kesenian Makassar sebagai lambang kehidupan sosial pemerintahan kolonial. Pemanfaatan Fort Rotterdam pada awal pembangunannya merupakan benteng pertahanan Kerajaan Gowa setelah direbut oleh pemerintah Belanda difungsikan sebagai pusat perdagangan, pemerintahan dan pemukiman. Pemanfaatan Fort Rotterdam kemudian berkembang menjadi daya tarik wisata hingga saat ini telah banyak dilaksanakan pemugaran sebagai usaha pelestarian serta menjadikan Fort Rotterdam layak dikunjungi oleh wisatawan.

Pemanfaatan Museum Kota (Gementeehuis) awalnya merupakan kantor walikota yang dibangun pemerintah Belanda. Setelah beberapa kali berubah fungsi pada tahun 2000 dijadikan Museum Kota yang menyimpan koleksi bersejarah yang menceritakan sejarah awal dan perkembangan Kota Makassar. Pemanfaatan Gedung Kesenian Makassar pada awal perkembangannya merupakan tempat penyelenggaraan acara resmi, pertunjukan sandiwara, dansa bagi pemerintah kolonial. Selama beberapa tahun setelah Indonesia merdeka Gedung Kesenian dimanfaatakan sebagai kantor pemerintahan, setelah masa reformasi Gedung Kesenian Makassar dimanfaatkan kembali sebagai pusat berkesenian.

Tahap perkembangan Fort Rotterdam digolongkan pada tahap pengembangan (development). Fort Rotterdam sebagai daya tarik wisata telah ditata apik dengan adanya ruang terbuka hijau, perawatan bangunan dan Museum La Galigo yang berlokasi di dalam kompleks Fort Rotterdam menambah daya tariknya. Museum Kota Makassar berada pada tahap eksplorasi (exploration) selain karena status museum yang masih dalam tahap persiapan, keadaan fisik bangunan serta fasilitas ruang pamer museum masih memerlukan peningkatan. Gedung Kesenian Makassar dikelompokkan dalam tahap eksplorasi (exploration) karena saat ini dapat dikatakan belum layak dikunjungi oleh wisatawan, gedung yang masih dalam proses perbaikan yang masih tersendat menyebabkan beberapa ruangan masih dalam kondisi rusak, 
panggung ruang tertutup dan terbuka kondisinya masih dalam proses perbaikan yang terhenti.

Strategi yang efektif untuk meningkatkan ketiga bangunan bersejarah sebagai wisata warisan budaya adalah dengan strategi intensif yang terdiri dari strategi pengembangan produk, penetrasi pasar dan pengembangan pasar. Strategi pada pengembangan Fort Rotterdam antara lain, penegakan aturan tentang zonasi dan peraturan pemerintah daerah, peningkatan aktivitas antara budaya lokal dan wisatawan peningkatan sumber daya manusia terhadap pelayanan di Fort Rotterdam. Strategi pengembangan pada Museum Kota berupa perbaikan dan penataan terhadap bangunan Museum Kota, fasilitas pencahayaan dan suhu ruangan serta museum dilengkapi dengan storage yang memadai serta pengembangan target pasar, yaitu dari pengunjung siswa sekolah diperluas menjadi wisatawan. Strategi pengembangan bagi Gedung Kesenian Makassar antara lain perbaikan terhadap fisik bangunan, pengadaan faslitas galeri yang memberikan penjelasan tetang sejarah Gedung Kesenian, dan adanya kejelasan struktur pengelola gedung sehingga terdapat jembatan komunikasi antara seniman dan pemerintah selaku penanggung jawab benda cagar budaya.

\section{UCAPAN TERIMA KASIH}

Penulis menyampaikan ucapan terima kasih kepada Prof. Dr. I Nyoman Darma Putra, M.Litt selaku Ketua Program Studi Kajian Pariwisata Progam Pascasarjana Universitas Udayana serta Pembimbing II atas arahan, kesabaran dan bimbingan dalam penyelesaian penelitian ini. Prof. Dr. I Nyoman Kutha Ratna, SU selaku pembimbing I atas dorongan dan arahan kepada penulis selama penelitian ini. Prof. Dr. I Nyoman Sirtha, SH.,MS., Dr. I Nyoman Madiun, M.Sc dan Dr. Ir. I Made Adhika, MSP selaku dosen penguji yang telah memberikan banyak masukan, saran dan koreksi untuk menyempurnakan tulisan ini. Drs. Syarifuddin Rahim. M.Si selaku Sekretaris Dinas Pariwisata dan Ekonomi Kreatif Sulawesi Selatan, Dra Hj. Nurul Chamisany selaku Kepala 
UPTD Museum Kota Makassar dan Balai Pelestarian Cagar Budaya Kota Makassar atas bantuan dan informasi selama proses penelitian ini.

\section{PROFIL PENULIS}

Rafika Hayati, S.ST.Par adalah mahasiswa Magister Kajian Pariwisata di Univeristas Udayana Denpasar. Ia menyelesaikan program studi Diploma IV dengan mengikuti program transfer perkuliahan dari Diploma III Manajemen Perjalanan Wisata, Akademi Pariwisata Makassar ke Fakultas Pariwisata, Universitas Udayana Denpasar. Pengalaman yang dimiliki di bidang pariwisata adalah pernah bekerja pada Biro Perjalanan wisata di Kota Makassar dan Denpasar.

\section{DAFTAR PUSTAKA}

Agusta Ivanovich. 1998. Metode Kualitatif. Lokakarya Metode Kualitatif. Bogor 11 Oktober 2005

Anonim. 2010. Undang-Undang Nomor 11 Tahun 2010 Tentang Cagar Budaya. Pemerintah Republik Indonesia

Anonim. 2005. Peraturan Daerah Kota Makassar Nomor 6 Tahun 2006 Tentang Rencana Tata Ruang Wilayah Kota Makassar 2005-2015. Pemerintah Republik Indonesia.

Anonim. 2007. Pengelolaan Koleksi Museum. Jakarta: Direktorat Museum, Direktorat Jenderal Sejarah dan Purbakala Departemen Kebudayaan dan Pariwisata.

Anonim. 2010. Peraturan Menteri Kebudayaan dan Pariwisata RI Nomor: PM.59/PW.007/MKP/2010.

Asmunandar. 2008. "Membangun Identitas Makassar Melalui Kota Kuna Makassar". (Tesis Program Studi Arkeologi). Yogyakarta: Universitas Gadjah Mada

Butler, R.W. 2011. "Tourism Area Life Cycle" dalam: Cooper Chris. Contemporary Tourism Reviews. Oxford: Goodfellow Publisher Limited

David, F.R. 2009. Manajemen Strategi Konsep. Jakarta: Salemba Empat. 
Heriyanto Albertus dan B. Sandjaja. 2006. Panduan Penelitian. Jakarta: Prestasi Pustaka.

Indrianto Agoes. 2007. Interpreting the Past-Creating Surabaya Heritage Trail. Dalam: Janet Cochrane, ed. Asian Tourism: Growth and Change. United Kingdom: Elsevier Hal: 357-368

Mansyur, Syahruddin. 2010. “Konstruksi Baru Pameran Museum Kota Makassar". (Tesis Program Studi Arkeologi). Jakarta: Universitas Indonesia

Masdoeki, Abdul Muttalib dan Bahru Kallupa. 1986. Benteng Ujung Pandang (Fort Rotterdam). Makassar: Suaka Peninggalan Sejarah dan Purbakala Sulawesi Selatan.

Natsir, Mohammad, Syahrawi Mannan dan Nurbuayh Abubakar. 2010. Bangunan Bersejarah di Kota Makassar. Makassar: Balai Pelestarian Cagar Budaya.

Nuraeda, Siti, Muhammad Masrury dan Agung Mokobombang. 2008. Album Sejarah dan Kepurbakalaan Sulawesi Selatan (Wisata Kultural Historis). Makassar: Dinas Kebudayaan dan Pariwisata Provinsi Sulawesi Selatan

Nuryanti, Wiendu. 2009. Sinergi Arsitektur dan Pariwisata dalam Membangun Indonesia Kreatif. Pidato Pengukuhan Jabatan Guru Besar pada Fakultas Teknik Universitas Gadjah Mada. Yogyakarta 8 Juni 2009.

Pitana, I Gede dan Ketut Surya Diarta. 2009. Pengantar Ilmu Pariwisata. Cetakan Pertama. Yogyakarta: Andi Offset.

Tika, Zainuddin dkk. 2013. Makassar Tempo Doeloe. Makassar: Kantor Arsip, Perpustakaan dan Pengolahan Data Pemerintah Kota Makassar bekerjasama dengan Lembaga Kajian dan Penulisan Sejarah Budaya Sulawesi Selatan.

Tika, Zainuddin dkk. 2013. Makassar Tempo Doeloe. Makassar: Kantor Arsip, Perpustakaan dan Pengolahan Data Pemerintah Kota Makassar bekerjasama dengan Lembaga Kajian dan Penulisan Sejarah Budaya Sulawesi Selatan.

Yusriana. 2011. “Arahan Kebijakan Revitalisasi Kawasan Benteng Ujung Pandang". (Tesis). Yogyakarta: Universitas Gadjah Mada. 


\title{
KAJIAN KENYAMANAN DAN KEAMANAN WISATAWAN DI KAWASAN PARIWISATA KUTA LOMBOK
}

\author{
Wahyu Khalik \\ Program Studi Magister Kajian Pariwisata \\ Universitas Udayana \\ E-mail: wahyukhalik_sstpar@yahoo.com
}

\begin{abstract}
Comfort and security are vital factors in tourism destination of Kuta Lombok with great tourism potential. However, this potential will not be desirable if the conditions are not created by comfort and security. This proves that there are factors that affect the comfort, community understanding of tourism awareness, and community participation in comfort and security of tourists. The study was conducted aimed to determine the factors that affect comfort and safety, the level of community understanding of tourism awareness, and community participation in the comfort and security of tourists in Kuta Lombok tourism.
\end{abstract}

This study examines the comfort and safety of tourists in tourism of Kuta Lombok are included in the descriptive study. Therefore, the research conducted through a qualitative approach. Methods of data collection through observation, interview and documentation. Decision is determined by the method of purposive, with 15 informants. The theory applied is the theory of structural functionalism which analyzed the factors and community participation, and motivation theory is applied to analyze the level of community understanding about tourism awareness. The analysis results of research conducted by qualitative descriptive analysis presents the results of research through a narrative supported by photographs.

The results of this study suggests that the comfort and safety factor is influenced by the low level of community understanding in the elements of tourism awareness through Sapta Pesona. The low raises community understanding of factors that affect comfort and safety as a factor of environmental aspects of parking management and environmental hygiene, factors of economic activity and the hawkers aspects trasnportation service providers as well as factors in the aspect of tourism access roads were damaged. Community participation in the comfort and security of tourists is not functioning optimally. This is caused by unsynchronization between organizations. Forms of community participation in the form of the participation into the 
organization and the coast guard and empowerment of communities in the festival. Based on those results of the three studies, the government of Central Lombok is expected especially for Culture and Tourism Department particular attention to the factors that affect comfort and safety, and the formation of tourism awareness with benchmarks Sapta Pesona.

Keywords: comfort, security, participation, tourists, community

\section{Pendahuluan}

Kenyamanan dan keamanan menjadi kondisi yang sangat Lpenting dalam industri pariwisata. Aspek tersebut pada dua dekade terakhir telah menjadi isu yang semakin besar dan mempunyai dampak yang sangat besar terhadap keberlangsungan aktivitas perjalanan dan pariwisata (Kövári dan Zimányi, 2011). Ancaman kenyamanan dan keamanan wisatawan dapat dipengaruhi dan disebabkan oleh beragam faktor, seperti aksi teroris, konflik lokal, bencana alam, perilaku sosial masyarakat dan penyakit menular sehingga hal tersebut dapat menyebabkan menurunnya rasa aman bagi wisatawan. Kenyamanan dan keamanan bagi wisatawan merupakan salah satu faktor yang menentukan keputusan untuk melakukan suatu perjalanan ke suatu destinasi pariwisata.

Pesatnya pertumbuhan industri pariwisata di Indonesia merupakan tantangan yang cukup kompleks dalam memberikan rasa nyaman dan rasa aman (comfort and safety) bagi wisatawan. Pada kenyataannya dalam suatu destinasi wisata, banyak wisatawan tidak mendapatkan rasa aman yang disebabkan oleh sikap dan perilaku tuan rumah atau host (pedagang asongan, pelayanan parkir, penawaran jasa pijat (massage) yang terlalu agresif, dan yang lainnya. Kasus seperti ini sering terjadi di kawasan pariwisata yang sedang berkembang.

Provinsi Nusa Tenggara Barat (NTB) memiliki daya tarik wisata yang tidak kalah indahnya dengan destinasi wisata yang ada di provinsi lain di Indonesia. Sebagai destinasi pariwisata yang sedang berkembang, pemerintah provinsi menekankan pada penataan objek wisata masing-masing kabupaten dalam acara Ra- 
pat Koordinasi (Rakor) Keterpaduan Program Provinsi dan Kabupaten/Kota di Hotel Lombok Raya, pada 7 Februari 2013 (http:// www.portalkbr.com/nusantara/nusatenggara/2454763_4265.html). Dalam RPJPD Kabupaten Lombok Tengah tahun 2011-2013, telah menganalisis isu-isu strategis pariwisata terkait pemberdayaan masyarakat dan desa yaitu: 1) Belum optimalnya peran serta lembaga dan organisasi kemasyarakatan untuk turut berperan serta dalam proses pembangunan, dan 2) Masih adanya kesenjangan gender adalah hal akses manfaat, dan partisipasi dalam pembangunan dan penguasaan terhadap sumber daya belum optimal.

Faktor kenyamanan dan keamanan pada suatu kawasan pariwisata merupakan nilai tambah dan perluang untuk dikunjungi oleh wisatawan. Sebagaimana yang dimaksudkan UNWTO (2004) bahwa destinasi wisata di negara berkembang sudah saatnya untuk memberikan alternatif berwisata dengan jaminan keselamatan dan rasa aman bagi wisatawan selama berwisata. Pada sisi lain, pembangunan sarana dan prasarana pariwisata telah dibangun seperti Bandara Internasional Lombok (BIL) yang diresmikan oleh Presiden Susilo Bambang Yudhoyono pada Oktober 2011, perbaikan infrastruktur jalan, peningkatan kualitas pelayanan pada pelabuhan, serta dibangunnya akomodasi yang bertaraf internasional. Pembangunan bertaraf internasional tersebut bertujuan untuk memberikan kenyamanan dan keamanan bagi wisatawan yang berkunjung ke Nusa Tenggara Barat, khususnya Pulau Lombok.

Pesatnya pertumbuhan pariwisata di Indonesia dengan daya tarik wisata yang beragam membuat jumlah kunjungan wisatawan terus mengalami peningkatan. Berdasarkan jumlah tingkat kunjungan wisatawan ke kabupaten Lombok Tengah pada lima tahun terakhir, baik wisatawan mancanegara maupun wisatawan nusantara mengalami peningkatan yaitu tahun 2008-2012. Pada tahun 2008 tercatat kunjungan wisatawan sebanyak 42.294 orang, terdiri dari wisatawan mancanegara yang mencapai 30.326 orang dan 11.968 wisatawan Nusantara. Tahun 2009 sebesar 50.028 wisatawan, tahun 2010 mengalami peningkatan yang tidak terlalu 
signifikan sebesar 50.266 wisatawan mancanegara dan nusantara. Pada tahun berikutnya (2011) jumlah kunjungan wisatawan terjadi peningkatan yaitu 66.798 dari jumlah wisatawan. Program Visit Lombok Sumbawa (VLS) 2012 memberikan keuntungan bagi peningkatan jumlah wisatawan ke Lombok Tengah, hal tersebut terbukti jumlah kunjungan wisatawan mancanegara sebesar 121.482 orang dan 218.991 wisatawan nusantara pada tahun 2012 (Dinas Kebudayaan dan Pariwisata Kabupaten Lombok Tengah, 2013). Pemerintah Kabupaten Lombok Tengah menyadari bahwa peningkatan yang terjadi tidak terlapas dari paritisipasi para pelaku wisata (masyarakat lokal). Sehingga pemerintah melakukan pembinaan masyarakat dengan melibatkan mereka dalam berbagai kegiatan yang terkait dengan wisatawan baik terlibat secara perorangan maupun secara bersama-sama.

Jumlah kunjungan wisatawan mancanegara (wisman) ke Indonesia pada Mei 2013 mencapai 700 ribu kunjungan atau naik 7,65\% dibandingkan jumlah kunjungan wisman pada Mei 2012, yang sebanyak 650.900 kunjungan. Begitu pula jika dibandingkan April 2013 yang naik sebesar 8,45 persen. Kenaikan jumlah kunjungan wisman terjadi disebagian besar pintu masuk utama, dengan persentase tertinggi tercatat di pintu masuk Bandara Internasional Lombok (BIL), Nusa Tenggara Barat sebesar 66.64 persen yang kemudian diikuti Bandara Adi Sucipto DI Yogyakarta 42.21 persen. Sedangakan posisi ketiga menurut data resmi statistik nasional mencatat Bandara Minangkabau, Sumatera Barat sebesar 30,93 persen (BPS. Perkembangan pariwisata dan Transportasi Nasional Mei 2013: No. 43/07/Th.XVI, 1 Juli 2013).

Peningkatan jumlah kunjungan yang terjadi merupakan cermin dari terus berkembangnya kepariwisataan Pulau Lombok. Dengan demikian untuk mempertahankan dan menambah jumlah kunjungan wisatawan pada tahun berikutnya, hal tersebut tidak terlepas dari pentingnya faktor kenyamanan dan keamanan. Pemerintah provinsi Nusa Tenggara Barat, dalam Peraturan Daerah No 9 tahun 1989 menetapkan 15 kawasan pariwisata yang berada di dua pulau, yaitu Pulau Lombok Tengah 9 kawasan 
pariwisata dan Pulau Sumbawa dengan 6 kawasan pariwisata (RPJMD NTB 2009-2013), salah satu kawasan pariwisata tersebut adalah kawasan pariwisata Kuta Lombok yang memiliki keindahan alam sebagai daya tarik wisata. Penyusunan RPJPD bertujuan untuk memberikan pemerataan dalam sektor pariwisata yang memiliki potensi. Dalam perancanaan tersebut terdapat permasalahan yang dapat mengancam pembangunan dalam sektor pariwisata. Parmasalahan seperti, kurangnya pemahaman masyarakat akan sadar wisata - sapta pesona (aman, tertib, bersih, sejuk, indah, ramah, dan kenangan), masih kurangnya penataan dan pengamanan objek wisata, dan belum terkaitnya sektor pariwisata dengan sektor-sektor lainnya.

Isulainyangberkembang padadestinasipariwisata(Kawasan Pariwisata Kuta adalah terjadinya tindakan asusila yang dilakukan salah seorang masyarakat lokal terhadap wisatawan asal Amerika "Michelle Elizabeth Gonzales" (Doc. Lombok Post-28/Juli/2011). Pencurian motor, pedagang asongan yang agresif, pembuangan sampah di sembarang tempat juga menyebabkan suasana yang tidak nyaman pada kawasan pariwisata Kuta Lombok. Hasil observasi sementara yang dilakukan mendapatkan informasi dari salah seorang warga desa (Riun) yang bekerja sebagai satpam pantai menyatakan bahwa keterlibatan masyarakat masih belum maksimal. "Keterlibatan masyarakat sementara ini yang terlihat hanya sebagai satpam" (Observasi, 12 Oktober2013). Partisipasi masyarakat secara langsung dapat dilihat dari penerimaan terhadap wisatawan, yang lebih berorientasi kepada keuntungan semata tanpa memikirkan dampak yang diakibatkan.

Penentuan kawasan pariwisata Kuta sebagai lokasi penelitian dilatar belakangi perkembangan kepariwisataan yang begitu pesat. Keindahan alam yang belum ditata secara maksimal dan masyarakat lokal yang belum merasakan sepenuhnya dampak positif dari kagiatan kepariwisataan. Pada fase pengembangan, kawasan pariwisata Kuta Lombok masih memerlukan penelitian yang diambil dari sudut pandang kenyamanan dan keamanan. Dengan demikian, permasalahan yang diangkat dalam penelitian 
ini adalah; Pertama, faktor-faktor apa yang memengaruhi ketidaknyamanan dan ketidak-amanan wisatawan. Kedua, bagaimana tingkat pemahamana masyarakat tentang sadar wisata, dan Ketiga, bagaimanan partisipasi masyarakat terhadap kenyamanan dan keamanan di kawasan pariwisata Kuta Lombok.

Tujuan penelitian ini adalah untuk mengetahui faktor-faktor yang memengaruhi ketidak-nyamanan dan ketidak-amanan wisatwan, mengetahui tingkat pemahaman masyarakat tentang sadar wisata, dan mengetahui partisipasi masyarakat terhadap kenyamanan dan keamanan di kawasan Kuta Lombok.

\section{Teori dan Metode}

Permasalahan tersebut dianalisis berdasarkan kajian sebelumnya yang dianggap relevan dan teori struktural fungsionalisme yang berasal dari Talcott Parson digunanakan untuk menganalisis fungsi-fungsi sosial masyarakat dalam mengendalikan faktor-faktor yang dapat memengaruhi kenyamanan dan keamanan, serta teori motivasi (kebutuhan) dari Abraham Maslow (dalam Chapman, 2001:4) untuk melihat tingkat pemahaman masyarakat tentang sadar wisata serta pemahaman terhadap unsur-unsur sapta pesona pariwisata.

Metode penelitian yang digunakan adalah metode penelitian kualitatif, dengan teknik pengumpulan data dilakukan dengan observasi, wawancara, dan dokumentasi. Melalui pendekatan tersebut diharapkan akan dapat membantu dalam mendapatkan variabel-variabel yang berkaitan dengan kajian kenyamanan dan keamanan wisatawan secara mendalam. Pengambilan informan dalam penelitian partisipatif ini dilakukan dengan cara purposive sampling yang dilakukan kepada 15 orang informan. Analisis dilakukan dengan menggunakan analisis deskriptif kualitatif terhadap data yang didapat dari lokasi penelitian. Seluruh hasil analisis data disajikan baik secara formal dan informal dalam bentuk foto, dan narasi atau pernyataan-pernyataan mengenai kenyamanan dan keamanan wisatawan di kawasan pariwisata Kuta Lombok. 


\section{Pembahasan}

Faktor-faktor yang memengaruhi kenyamanan dan kemanan yaitu faktor lingkungan, faktor kegiatan ekonomi dan faktor akses jalan pariwisata. Pertama, faktor lingkungan berdasarkan hasil penelitian terdapat dua aspek yang memiliki pengaruh terhadap ketidak-nyamanan dan ketidak-aman wisatawan yaitu pengelolaan areal parkir dan kebersihan lingkungan. Pengelolaan tempat parkir di kawasan pariwisata Kuta Lombok masih belum jelas, walaupun diketahuibahwa penjagaan dan pemungutan biaya parkir dilakukan oleh pihak satpam pantai. Pengelolaan tempat parkir dan besaran biaya parkir sering membuat pengunjung merasa tidak nyaman. Berdasarkan keterangan dari salah satu wisatawan asal Manado (Bapak Ferdi) mengenai besaran retribusi masuk pada objek wisata di kawasan pariwisata Kuta Lombok, disela kunjungan tugasnya ke Dinas Pendidikan dan Olahraga di Mataram. “....pantai Kuta bagus ya! tapi saya terkejut dengan retribusi yang terlalu tinggi. Tadi ketika saya ke toilet, diminta lagi". (Wawancara, tgl 10 desember 2013). Pernyataan tersebut diutarakan ketika wisatawan tersebut merasakan suasana yang tidak ramah dari pedagang asongan. Beliau juga kemudian mengkritik masalah kebersihan di sekitar pantai.

Kebersihan lingkungan sekitar kawasan pariwisata merupakan hal yang paling penting. Kurihara (2010) mengklasifikasikan bahwa keadaan lingkungan sekitar kawasan wisata bahwa lingkungan tersebut harut terjaga kebersihan dengan tidak membuang sampah sembarangan dan kebersihan pada fasilitas umum. Kondisi sampah yang demikian membuat kenyaman menjadi terganggu, hal demikian memerlukan kesadaran masyarakat untuk tidak membuang sampah sembarangan. Perilaku masyarakat yang membuang sampah khususnya masyarakat yang berada di sekitar kampung nelayan dianggap mengganggu kenyamanan wisatawan. Arwata (dalam Jumail, 2012: 80) mengindikasikan bahwa adanya ketidak-seimbangan pemanfaatan ruangyangberakibat pada permasalahan lingkungan seperti munculnya rumah kumuh, tumpukan sampah, dan 
limbah. Hasil observasi mengenai faktor kebersihan lingkungan di sepanjang pantai (Pantai Kuta, Seger, dan Aan) pada kawasan pariwisata Kuta Lombok memang masih belum ada tempat sampah yang disediakan oleh petugas satpam pantai. Di satu sisi, terlihat kebingungan dari masyarakat terhadap kebersihan terutama mengenai tempat pembuangan akhir sampah yang tidak ditentukan. Jika ditinjau dari Perda Kabupaten Lombok Tengah no.7 tahun 2011 pasal 48 huruf (a) yang menerangkan bahwa Tempat Pemrosesan Akhir (TPA) sampah tidak diperkenankan terletak berdekatan dengan kawasan permukiman (RTRW Kab. Lombok Tengah 2011-2031).

Kedua adalah faktor kegiatan ekonomi seperti aktifitas pedagang asongan dan sikap penyedia jasa transportasi. Sikap agresif pedagang asongan merupakan faktor yang menyebabkan ketidak-nyamanan dan ketidak-amanan wisatawan di kawasan pariwisata Kuta Lombok. Perilaku tersebut umum terjadi pada objek wisata, dalam penelitian yang dilakukan bahwa pedagang asongan adalah anak-anak yang masih sekolah. Kepala Desa Kuta menerangkan bahwa pedangang asongan yang berada di kawasan Pariwisata Mandalika (Kawasan Pariwisata Kuta, Seger, Aan) berasal dari desa tetangga, sebagian besar berasal dari Sade dan Rembitan. Ditambahkan pula bahwa pihak Desa Kuta telah memaksimalkan penertiban pedagang asongan dan pedagang kaki lima, akan tetapi mendapatkan perlawanan dari para pedagang. Kenyamanan dan keamanan wisatawan di kawasan pariwisata Kuta Lombok masih kurang.

Jasa transportasi merupakan salah satu jenis usaha yang menjadi kebutuhan wisatawan. Jasa penyewaan kendaraan dari segi fungsional bertujuan memberikan kemudahan bagi wisatawan untuk mencapai objek wisata yang diinginkan. Lalu Rian menjelaskan jenis jasa transportasi yang terdapat di kawasan pariwisata Kuta Lombok yaitu kendaraan roda empat (mobil) dan kendaraan roda dua (motor) (Wawancara, tgl 18 April 2014). Penyedia jasa transportasi khusus untuk jasa transportasi mobil di bagi tiga yaitu kelompok satu di Pantai Kuta yang disebut 


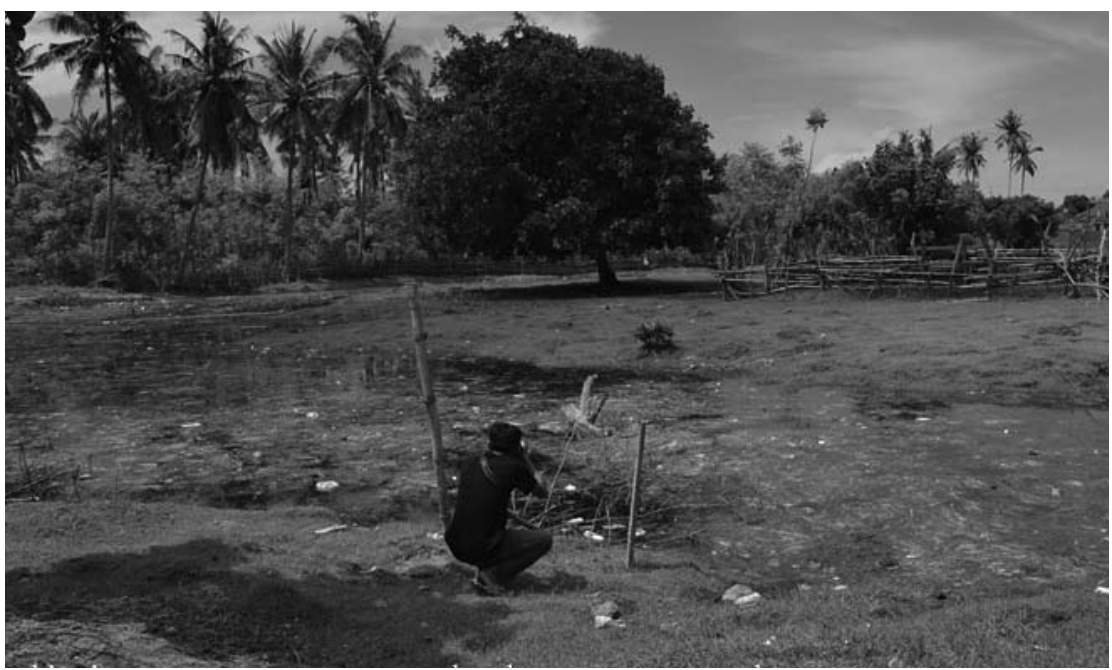

Kondisi muara yang penuh dengan sampah di depan Cafe Magic, Kuta, Lombok (Foto: Wahyu Khalik)

juga dengan sebutan Roy Pantai. Kedua, yaitu di Pantai Seger yang terletak di sebelah Novotel Kuta Lombok, dan ketiga di Pantai Aan yaitu pantai yang terletak si bagian timur kawasan pariwisata Kuta Lombok. Penciptaan rasa nyaman dan aman tentu tidak hanya berasal dari sikap tuan rumah (host) tetapi juga sikap wisatawan (guest). Greenwood (dalam Pitana, 2005:83) melihat bahwa hubungan antara wisatawan dan masyarakat lokal menyebabkan terjadinya proses komodititasi dan komersialisasi dari keramahan masyarakat lokal. Perspektif komodititasi dan komersialisasi tersebutmenyebabkan kedua pihak bertujuanuntuk menguntungkan diri sendiri. Sehingga tercipta ketidakamanan dan nyamanan di kalangan masyarakat lokal sebagai tuan rumah (host) dan wisatawan sebagai (guest).

Faktor akses merupakan kunci pada suatu destinasi pariwisata, akses berupa jalan menuju pantai Aan di sebelah timur Kawasan Pariwisata Kuta Lombok memiliki kualitas jalan yang masih kurang baik dan perlu mendapatkan perhatian yang lebih serius. Aspek kenyamanan dan keamanan tidak terlepas dari bagaimana cara untuk mencapai suatu objek wisata. Jalan merupakan salah satu dari empat unsur yang harus ditemukan 


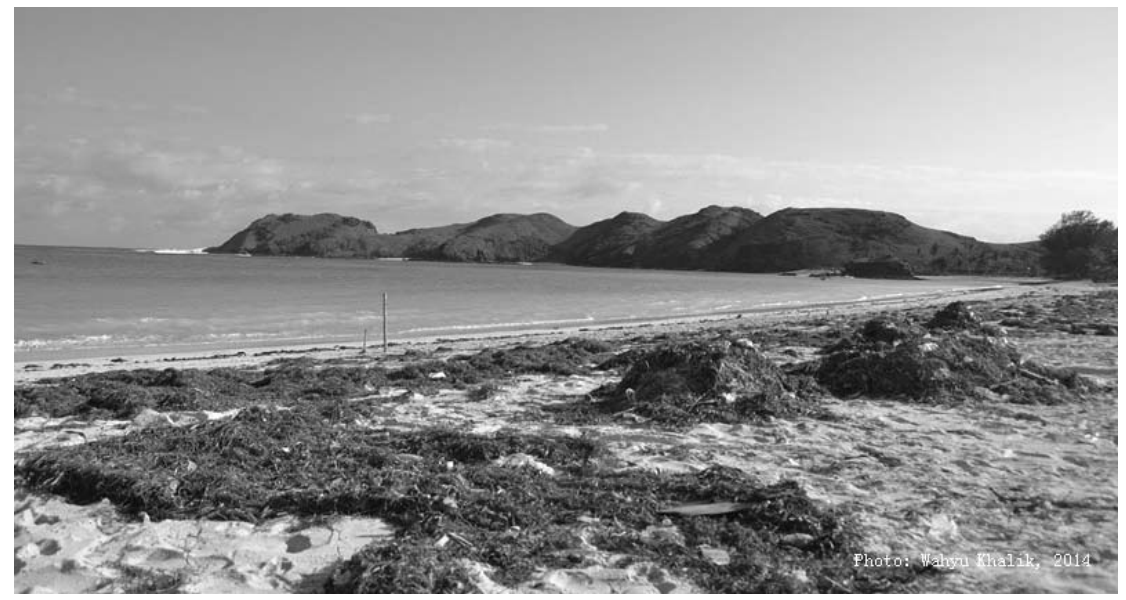

Sampah plastik dan organik di sepanjang Pantai Aan di kawasan pariwisata Kuta, Lombok (Foto: Wahyu Khalik)

dalam pengembangan pariwisata sehingga wisatawan merasa aman dan nyaman dalam mencapai objek yang ingin dituju.

Teori motivasi yang mendukung teori struktural fungsionalisme digunakan untuk mengkaji tingkat kesadaran wisata masyarakat melalui unsur sapta pesona pariwisata. Motivasi merupakan satu penggerak dalam hati seseorang utuk melakukan atau mencapai sesuatu tujuan, dengan kata lain motivasi adalah sebuah proses untuk tercapainya suatu tujuan. Motivasi dapat diartikan sebagai kekuatan (energi) seseorang yang dapat menimbulkan tingkat persistens dan antusiasmenya dalam melaksanakan suatu kegiatan, baik yang bersumber dari diri individu itu sendiri (motivasi intrinsik) maupun dari luar individu (motivasi ekstrinsik) (Sudrajat, 2008: 4).

Tingkat pemahaman masyarakat tentang sadar wisata yang diukur melalui unsur sapta pesona di kawasan pariwisata Kuta Lombok masih rendah. Hal ini tercermin pada unsur keamanan dan ketertiban yang sebagian masyarakat masih mengganggu wisatawan. Indikator keamanan secara umum pada objek wisata, yaitu sikap tidak mengganggu wisatawan, menjaga keamanan lingkungan, tidak ada premanisme dan hal yang berkaitan dengan keamanan fisik. Unsur kebersihan, masyarakat masih kurang menyadari pentingnya kebersihan sehingga tidak heran 


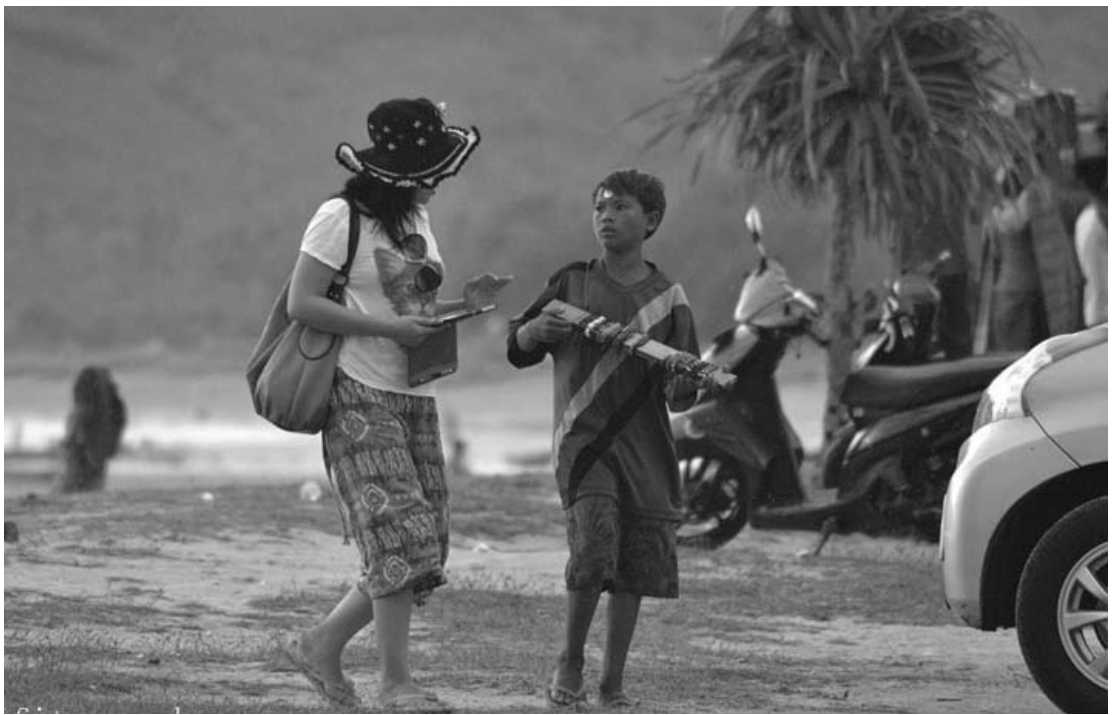

Agresifitas pedagang asong di kawasan pariwisata Kuta, Lombok (Foto: Wahyu Khalik)

mereka membuang sampah sembarangan yang menyebabkan lingkungan yang kurang bersih. Hasil observasi menunjukkan tingkat pemahaman masyarakat terhadap kebersihan masih kurang. Kurangnya pemahaman tentang arti kebersihan jika dipandang dari sudut pandang kesehatan lingkungan bahwa membuang sampah sembarangan dapat menyebabkan penyakit dan dapat merusak ekosistem yang ada di sekitar. Masalah kebersihan lingkungan menjadi hal yang sangat serius pada suatu objek wisata seperti ditemukannya banyak sampah yang terdapat di sepanjang pantai, di pinggir jalan bahkan di tempat umum.

Kurangnya pemahaman masyarakat terhadap pentingnya kebersihan berimbas pada unsur kesejukan dan keindahan lingkungan di kawasan pariwisata Kuta Lombok. Hasil observasi di lapangan memberikan gambaran bahwa masyarakat lokal setempat masih kurang sadar dalam hal pelestarian lingkungan. Akan tetapi berbeda dengan hasil wawancara yang didapat bahwa terdapat beberapa alasan yang diungkapkan.

“... disinikan daerah kering, masyarakat sebenarnyaberharap pemerintah mengadakan program penghijauan. Kalau masyarakat sendiri, mungkin hanya sekedar di rumah saja, itu juga kadang-kadang tidak diurus. 
Dalam jumlah besar, kan perlu perawatan dan tau sediri keadaan air seperti apa di daerah selatan". (Wawancara, tgl 18 April 2014).

Analisis hasil wawancara kepada Lalu Amanah bahwa masyarakat berharap pemerintah membuat suatu program yang berkaitan dengan pelestarian lingkungan. Di samping itu, masyarakat memerlukan antusiasme dari steakholer yang lain untuk turut serta dalam program pelestarian secara berkelanjutan. Pegembangan pariwisata berkelanjutan membutuhkan paritisipasi informasi dari semua pihak terkait agar prosesnya berkesinambungan dan memerlukan pemantauan konstan terhadap dampak yang ditimbulkan (UNEP and UNWTO, 2005:11-12).

Tingat pemahaman masyarakat terhadap unsur ketidakramahan tercermin dari sikap yang menganggap bahwa mereka harus mendapatkan sesuatu (imbalan) dari wisatawan atau beroientasi pada keuntungan pribadi. Dengan demikian, unsur ini adalah proses pemberian kesan dan kenangan, berdasar dari sikap masyarakat yang kurang memahami keenam unsur sapta pesona, maka masyarakat (host) dan destinasi pariwisata menjadi objek yang dibicarakan oleh wisatawan setelah kembali ke daerah asal. Setiap daerah tujuan wisata mempunyai image tertentu, yaitu mental maps seseorang terhadap suatu destinasi yang mengandung keyakinan, kesan, dan persepsi. Gambaran yang terbentuk di pasar merupakan kombinasi antara berbagai faktor yang ada pada destinasi yang bersangkutan seperti cuaca, pemandangan alam, keamanan, kesehatan dan situasi, keramahtamahan dan lain-lain (Pitana, 2005;64).

Kenangan merupakan unsur sapta pesona yang dijadikan sebagai penentu terhadap keberlangsungan suatu objek wisata. Artinya, evaluasi atau persepsi dari enam unsur sebelumnya yang menjadi gambaran kondisi objek wisata selama wisatawan tersebut tinggal. Jika ditinjau kembali terhadap pembahasan pada bab sebelumnya tentang faktor yang memengaruhi ketidaknyamanan dan amanan, maka dapat digambarkan bahwa kenangan yang didapat wisatawan mengenai objek wisata di Kuta 


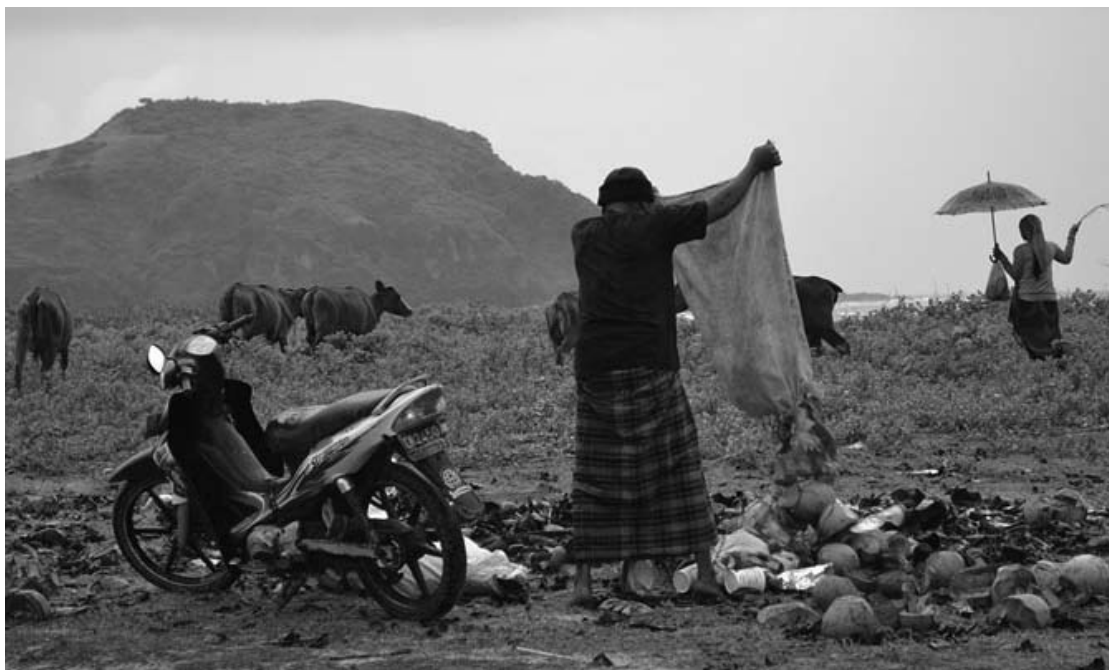

Minimnya pemahaman masyarakat setempat tentang kebersihan di kawasan pariwisata Kuta, Lombok (Foto: Wahyu Khalik)

Lombok menjadi kurang baik dan dapat menyebabkan turunnya tingkat kunjungan wisatawan baik wisatawan nusantara maupun wisatawan mancanegara.

Keterlibatan masyarakat lokal secara langsung dengan wisatawan sebagai dampak perkembangan pariwisata Kuta Lombok menyebabkan dua katagori kenangan yang didapat, yaitu kenangan yang bersifat positif dan negatif. Pernyataan yang diberikan merupakan (Robins, 1999: 124) persepsi dimana individu mengorganisasikan dan menafsirkan kesan-kesan indra mereka untuk memberikan makna terhadap lingkunanannya. Respon positif terhadap keindahan alam di kawasan pariwisata Kuta Lombok merupakan kenangan yang mampu memberikan kenyamanan psikologis sehingga wisatawan dapat mengabadikannya sebagai kenangan yang indah. Potensi alam tersebut merupakan aset yang sangat berharga bagi Kabupaten Lombok Tengah khususnya mayarakat lokal yang berada di desa Kuta Lombok.

Masyarakat Kuta Lombok yang terdiri dari berbagai latar belakang pendidikan dan mata pencaharian memiliki bentuk tersendiri untuk berpartisipasi terhadap kenyamanan dan keamanan wisatawan di Kawasan Pariwisata Kuta Lombok. 
Masyarakat yang antusias mendukung perkembangan pariwisata Kuta harus turutserta dalam keberlangsungan aktivitas pariwisata. Dimana kunci keberhasilan pada suatu kawasan pariwisata sangat ditentukan dari peran aktif atau partisipasi masyarakat tersebut. Bentuk partisipasi masyarakat secara tidak langsung untuk menjaga kenyamanan dan keamanan di kawasan pariwisata Kuta Lombok berupa pendelegasian atas partisipasi masyarakat melalui organisasi yang dibentuk, yaitu pembentukan Satpam Pantai dan organisasi masyarakat. Faktanya, dalam intern masyarakat di desa Kuta masih terpaku pada kepentingan kelompok. Kondisi masyarakat yang dianggap telah berhasil adalah dapat menghindari perpecahan antar anggota masyarakat, ketidakpastian dari anggota masyarakat, peperangan sosial (konflik), dan pemerasan masyarkat terhadap anggota masyarakat yang lain (Zeitlin, 1995). Analisis perilaku tersebut dapat dimaknai bahwa keamanan dan kenyamanan pada intern masyarakat masih belum berfungsi dengan maksimal.

Paradigma pembangunan berkelanjutan dalam industri pariwisata sering menggunakan pendekatan partisipatoris. Hal ini terkait dengan individu sebagai mahluk sosial yang tidak mungkin melepaskan diri dari berbagai keadaan yang ada di sekelilingnya. Conyers (dalam Noraini, dkk., 2011: 58-67) mengemukakan tiga alasan utama partisipasi masyarakat dalam pembangunan, yaitu: (1) Partisipasi masyarakat merupakan suatu alat guna memperoleh informasi mengenai kondisi, kebutuhan dan sikap masyarakat setempat, yang tanpa kehadirannya program pembangunan dan proyek akan gagal, (2) Masyarakat akan mempercayai program pembangunan jika dilibatkan dalam proses persiapan dan perencanaannya, karena masyarakat lebih mengetahui seluk beluk proyek dan merasa memiliki proyek tersebut, dan (3) Partisipasi merupakan hak demokrasi masyarakat dalam keterlibatannya di pembangunan.

Konsep partisipasi dalam penelitian ini menganalisis bentuk partisipasi masyarakat terhadap kenyamanan dan keamanan di kawasan pariwisata Kuta Lombok. Untuk menjaga kenyamanan 
dan keamanan, anggota masyarakat berpartisipasi melalui keikut-sertaan dalam pam swakarsa. Bina Masyarakat Wisata (BMW) merupakan salah satu wujud partisipasi masyarakat dalam bentuk organisasi kepariwisataan dengan fungsi untuk memberikan pemahaman kepariwisataan kepada masyarakat. Bentuk organisasi (pam swakarsa) lainnya adalah Jejak Kumpul, Amphibie, Bumi Gora, dan Putra Angkasa. Empat organisasi masyarakat lainnya memiliki tujuan yang sama, yaitu untuk menjaga keamanan. Akan tetapi, peran keempat organisasi masyarakat tersebut belum optimal terhadap pariwisata. Karena merupakan organisasi pada intern masyarakat itu sendiri.

Teori fungsional-struktural adalah sesuatu yang urgent dan sangat bemanfaat dalam suatu kejadian tentang analisa masalah sosial dan memiliki pengaruh yang besar dalam ilmu sosial di abad sekarang (Arina, 2012). Menurut Parson terdapat empat fungsi penting yang mutlak dibutuhkan bagi semua sistem sosial, yaitu Adaptation (A), pencapaian tujuan atau Goal attainment (G), Integration (I), dan Latency (L) atau dengan singkatan AGIL (Hasan Sarif, 2009). Menurutnya, semua fungsi tersebut wajib dimiliki oleh semua sistem agar tetap bisa bertahan. Adaptation merupakan fungsi yang sangat penting, sistem harus dapat beradaptasi dengan cara menanggulangi situasi eksternal yang gawat, dan sistem harus bisa menyesuaikan diri dengan lingkungan juga dapat menyesuaikan lingkungan dengan kebutuhannya. Goal attainment yaitu pencapaian tujuan yang sangat penting, dimana sistem harus bisa mendefinisikan dan mencapai tujuan utamanya. Integration artinya sebuah sistem harus bisa mengatur dan menjaga antar hubungan bagian-bagian yang menjadi komponennya, selain itu mengatur dan mengelola ketiga fungsi (AGL). Latency yaitu sistem harus mampu berfungsi sebagai pemelihara pola, subuah sistem harus memelihara dan memperbaiki motivasi pola-pola individu dan kultural.

Parson, 1951: 5-6 (dalam Treviňo, 2001) mendefinisikan sistem sosial terdiri dari sejumlah aktor-aktor individual yang saling berinteraksi dalam situasi yang sekurang-kurangnya mem- 
punyai aspek lingkungan atau fisik, aktor-aktor yang mempunyai motivasi dalam arti kecenderungan untuk mengoptimalkan kepuasan yang hubungannya dengan situasi mereka didefinisikan dan dimediasi dalam term system simbol bersama yang terstruktur secara kultural. Dari pandangan teori fungsionalisme struktural digunakan untuk mengkaji partisipasi masyarakat dan pemberdayaan masyarakat sebagai anggota yang merupakan syarat mutlak dalam pembangunan pariwisata berkelanjutan, agar masyarakat tidak merasa terpinggirkan atau merasa sebagai penonton saja. Lemahnya partisipasi masyarakat pada umumnya dipengaruhi oleh faktor kondisi sosial ekonomi masyarakat yang masih rendah, sehingga tidak mampu dan takut untuk berpartisipasi. Dalam hal pemberian rasa nyaman dan aman di kawasan pariwisata Kuta Lombok masyarkat diberdayagunakan antara lain berupa pemberdayaan masyarakat dalam kegiatan pariwisata seperti, masyarakat diikut-sertakan kedalam festival Putri Mandalika, jasa perahu kepada wisatawan oleh penduduk di kampung nelayan. Dubois dan Miley (1992: 211) menyatakan bahwa proses pemberdayaan masyarakat memerlukan tiga tahapan yaitu penyadaran, pengkapasitasan, dan pendayaan.

\section{Simpulan}

Berdasarkan permasalahan, hasil dan pembahasan tentang kajian kenyamanan dan keamanan wisatawan di kawasan pariwisata Kuta Lombok maka dapat disimpulkan bahwa tingkat pemahaman masyarakat tentang sadar wisata dengan tolok ukur unsur sapta pesona masih rendah. Ini membuktikan bahwa fungsi sosial masyarakat dalam menjaga keamanan, ketertiban, kebersihan, kesejukan, keindahan, keramahan dan kenangan tidak berfungsi dengan baik secara sistem untuk mencapai tujuan pariwisata yang berdaya saing tinggi.

Rendahnya pemahaman masyarakat tentang sadar wisata menimbulkan beberapa faktor yang berimplikasi terhadap ketidak-nyamanan dan ketidak-amanan wisatwan di kawasan pariwisata Kuta Lombok. Pertama, faktor lingkungan dari aspek 
pengelolaan parkir yang tidak teratur dan kebersihan lingkungan di sekitar kawasan pariwisata Kuta Lombok. Kedua, faktor kegiatan ekonomi yang dilihat dari aspek yang paling dirasakan wisatawan sebagai aspek ketidak-nyamanan adalah pedagang asongan yang terlalu agresif serta penyedia jasa transportasi yang masih beorientasi pada keuntungan sepihak. Ketiga adalah faktor askses menuju objek wisata di kawasan pariwisata Kuta Lombok, yaitu dari aspek jalan yang memiliki kondisi yang masih rusak.

Bentuk partisipasi masyarakat terhadap kenyamanan dan keamanan berupa keikutsertaan masyarakat pada beberapa organisasi masyarakat seperti Jejak Kumpul, Amphibie, Putra Angkasa, Bumi Gora, dan Bina Masyarakat Wisata serta Satpam Pantai. Organisasi masyarakat yang berkaitan langsung dengan pariwisata adalah satpam pantai yang bertanggungjawab menjaga kenyaman dan keamanan di pantai dan Bina Masyarakat Wisata yang bertujuan untuk membina, memberdayakan, serta memberikan pemahaman pariwisata kepada masyarakat. Kemudian, empat organisasi masyarakat yang lain belum berfungsi optimal terhadap kenyamanan dan keamanan. Hal itu menegaskan bahwa partisipasi masyarakat terhadap kenyamanan dan keamanan wisatawan di kawasan pariwisata Kuta Lombok masih rendah.

\section{Saran}

Berdasarkan hasil penelitian yang dilakukan, terdapat beberapa hal yang perlu diperhatikan oleh steakholder terkait dengan kajian kenyamanan dan keamanan wisatawan di kawasan pariwisata Kuta Lombok.

Pertama. berdasarkan faktor lingkungan yang memengaruhi ketidak-nyamanan dan ketidak-amanan wisatawan seperti pengelolaan parkir, diharapkan Dinas Budaya dan Pariwisata diharapkan berkoordinasi dengan dinas terkait guna untuk mengatur penglolaan areal parkir baik berupa penataan sehingga wisatawan tidak parkir sembarangan. Kemudian diharapkan pihak Desa Kuta untuk berkoordinasi dengan dinas terkait untuk menyediakan dan menentukan tempat pembuangan akhir dan 
tempat sampah di Pantai Kuta, Seger, dan Aan untuk menjaga kebersihan lingkungan serta memberikan pemahaman kebersihan kepada masyarakat. Faktor kegiatan ekonomi baik berupa pedangan asongan dan penyedia jasa transportasi diperlukan pihak Desa Kuta dan Pemkab Lombok Tengah untuk terus mengawasi sikap agresif mereka sehingga tidak menggangu kenyamanan dan keamanan wisatawan. Sedangkan diharapkan kepada Pemkab Lombok Tengah untuk memperhatikan akses jalan pariwisata menuju objek wisata di kawasan pariwisata Kuta Lombok.

Kedua, dalam menerapkan unsur sapta pesona pariwisata (aman, tertib, bersih, sejuk, indah, ramah, dan kenangan) diperlukan pembentukan kelompok sadar wisata dari Desa Kuta, dan memberikan penyuluhan secara berkala kepada masyarakat. Terkait dengan hal tersebut, diharapkan masyarakat lokal untuk menumbuhkan kesadaran dari dalam diri (intern) masyarakat sebagai dasar pemahaman awal mengenai sapta pesona.

Ketiga, berdasarkan hasil penelitian mengenai kajian kenyamanan dan keamanan wisatawan, hal-hal yang perlu diperhatikan oleh pihak Desa Kuta adalah pembentukan kelompok sadar wisata dengan tidak memandang masyarakat dari anggota pam swakarsa manapun sehingga tercapai tujuan bersama yaitu menciptakan suasana nyaman dan aman bagi wisatawan. Pihak Desa Kuta diharapkan membentuk sebuah koperasi bersama terkait dengan penyediaan jasa pariwisata melalui pengelolaan yang transparan dengan tujuan meratakan pendapatan masyarakat dari sektor pariwisata. Satpam pantai diharapkan ketegasan dalam menjalankan aturan demi keamanan dan ketertiban serta kenyamanan wisatawan.

Diharapkan hasil temuan dalam penelitian ini dapat menjadi acuan kepada Pemkab Lombok Tengah dan pihak terkait dalam memperhatikan kenyamanan dan keamanan dalam pengelolaan kawasan pariwisata agar tercipta suasana yang nyaman dan aman demi keberlangsungan pariwisata Kuta Lombok. 


\section{UCAPAN TERIMA KASIH}

Terima kasih kepada disampaikan khusus kepada Ketua Program Studi S2 Kajian Pariwisata Prof. Dr. I Nyoman Darma Putra, M.Litt, dan Prof. Dr. I Nyoman Sirtha, SH., MS selaku Ketua Program Studi Kajian Pariwisata sebelumnya atas kesempatan, bantuan dan fasilitas yang diberikan selama studi. Pembimbing I, Prof. I Wayan Ardika, M.A dan Pembimbing II Prof. Dr. Drs. A.A. Ngurah Anom Kumbara, MS, Anggota Penguji Prof. Dr. I Nyoman Sirtha, SH., MS dan Dr. Ir. Syamsul Alam Paturusi, MSP, serta Drs. I Nyoman Sunartha, M.Si. atas bimbingan, saran dan masukannya. Terima kasih tidak lupa diucapkan kepada Direktur Akpar Mataram Dr. Halus Mandala, M.Hum. Kepala Bappeda dan Disbudpar serta staff dinas terkait Kabupaten Lombok Tengah atas bantuannya.

\section{PROFIL PENULIS}

Wahyu Khalik, S.ST.Par, adalah mahasiswa kajian pariwisata Universitas Udayana, Bali. Menyelesaikan program Diploma III di Akademi Pariwisata Mataram tahun 2008 dengan gelar AMd. Par. Diploma IV di Fakultas Pariwisata, Universitas Udayana, Bali tahun 2011. Program magister pariwisata Universitas Udayana tahun 2014. Tahun 2006-2007 bekerja di di Sheraton Senggigi, Lombok. Pernah bekerja di The Oberoi Lombok tahun 2007. Tahun 2009-2010 bekerja di Moevenpick Hotel, Yanbu - Saudi Arabia.

\section{DAFTAR PUSTAKA}

Arina, Apri. 2012. Sosiologi: Latar Belakang Teori Fungsional-Struktural. Diakses: 26 September 2013. Tersedia pada: http://rhyenaaprii. blogspot.com/2012/11/makalah-sosiologi.html

Conyers, Diana. 1991. Perencanaan Sosial di Dunia Ketiga. Yogyakarta: Universitas Gadjah Mada.UGM Press.

Depbudpar. 2006. Buku Saku Sadar Wisata dan Sapta Pesona (Pengertian, Penerapan, dan Manfaatnya). Jakarta: Dirjen Pengembangan Destinasi Pariwisata.

Hasan, Sarif. 2010. Fungsionalisme Struktural Talcott Parson. Diakses, 
tanggal 26 Oktober 2013. Tesedia pada: http://saripuddin. wordpress.com/fungsionalisme-struktural-talcott-parsons/

Resmayasari, Ira. 2011. What is the Perception of French Tourist about "The Island of Paradise?". Udayana University - Universite Angers: Indonesia - France Double Degree Program. Master Program of Tourism Studies.

Jumail, Mohamad. 2011. Pencitraan Kawasan Wisata Kuta Lombok Tengah. Universitas Udayana: Program Magister Kajian Pariwisata.

Kövári, István dan Zimányi, Krisztina. 2011. Safety and Security in the Age of Global Tourism (The changing role and conception of Safety and Security in Tourism). Budapest. Agroinform Publishing House.

Maslow, Abraham H. 1984. Motivasi dan Kepribadian: Teori Motivasi dengan Ancangan Hirarki Kebutuhan Manusia (judul asli: Motivation and Personality). Diterjemahkan oleh Nurul Iman. Jakarta: PT. Pustaka Binaman Pressindo.

Mthembu, Nompumelelo. 2009. Tourism Crime, Safety and Security in the Umhlathuze District Municipality, Kwazulu - Natal. Kwadlangezwa: Universitas of Zululand - Faculty of Arts in Partial Fulfilment of the Requirements fot the Master's in Recreation and Tourism at the Department of Recreation and Tourism.

Noraini, dkk. 2011. Decentralization and Participatory Rural Development: A Literature Review. Malaysia: Technology University of Malaysia. Vol. 5 | Issue 4 | 2011 | 58-67

Saripuddin. 2009. Sosiologi Kritis: Fungsionalisme Struktural Talcott Parsons. Diakses: 23 November 2013. Tesedia pada: http:// saripuddin.wordpress.com/fungsionalisme-struktural-talcottparsons/

Sudrajat, Akhmad. 2008. Teori Motivasi (Pendidikan). Diakses:05 Desember 2013. Tersedia pada: akhmadsurdajat.wordpress.com/2008/02/06/ teori-teori-motivasil

Tunggal, Hadi Setia. 2009. Undang-Undang Kepariwisataan (Undangundang R.I. No. 10/2009). Jakarta: Harvarindo.

UNWTO and UNEP. 2004. Making Tourism More Sustainable - A Guide for Policy Makers, p.11-12.

UNWTO. 1994. United Nations and WTO (Recommendation on Tourism Statistics) Series M No.83. New York: Department for Economic and Social Information and Policy Analysis Statistical Division and World Tourism Organization. 